\title{
Changes in nutritional components and antioxidant activities from soybean leaves containing high isoflavone contents according to different storage temperatures and periods
}

\author{
Hee Yul Lee ${ }^{1}$ Dong Hee $\mathrm{Lee}^{2} \cdot \mathrm{Su} \mathrm{Cheol} \mathrm{Kim}^{1} \cdot$ Du Yong Cho ${ }^{1} \cdot \mathrm{Kye} \mathrm{Man} \mathrm{Cho}^{1}$ (D)

\section{고 이소플라본 함유 콩잎의 저장 온도와 기간에 따른 영양학적 성분과 항산화 할성 변화}

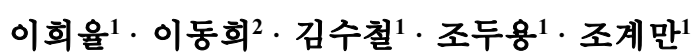

\begin{abstract}
This study investigated that change of the nutrients (including fatty acids, amino acids, and minerals) and total phenolic (TP), total flavonoid (TF), and isoflavone contents and antioxidant activities during the storage of soybean leaves containing high isoflavone contents at 5,25 , and $55^{\circ} \mathrm{C}$ for 180 days. The contents of free amino acids were increased from $1313.81 \mathrm{mg} / 100 \mathrm{~g}$ at 0 day to $1776.15,1693.93$ and $1551.18 \mathrm{mg} /$ $100 \mathrm{~g}$ at 5,25 , and $55{ }^{\circ} \mathrm{C}$ storage for 180 days, respectively, but the values of fatty acids were little unchanged. The contents of minerals were detected from $51.65 \mathrm{mg} / 100 \mathrm{~g}$ ( 0 day) to 49.93 $\left(5{ }^{\circ} \mathrm{C}\right), 50.20\left(25^{\circ} \mathrm{C}\right)$, and $61.21\left(55^{\circ} \mathrm{C}\right) \mathrm{mg} / 100 \mathrm{~g}$ at 180 days, respectively. The levels of total isoflavones did not change during the storage periods. In case of storage at $55{ }^{\circ} \mathrm{C}$, the contents of glycosides $(1347.78 \rightarrow 2195.13 \mu \mathrm{g} / \mathrm{g})$ and aglycones $(342.79 \rightarrow$ $480.61 \mu \mathrm{g} / \mathrm{g}$ ) increased during storage, while the levels of malonylglycosides $(2209.22 \rightarrow 1289.48 \mu \mathrm{g} / \mathrm{g})$ decreased. Also, the
\end{abstract}

Kye Man Cho $(\triangle)$

E-mail:kmcho@gntech.ac.kr

${ }^{1}$ Department of Food Science, Gyeongnam National University of Science and Technology, Jinju 52725, Republic of Korea

${ }^{2}$ Industry Academy Cooperation Foundation, Andong National University, Andong 36729, Republic of Korea

This is an Open Access article distributed under the terms of the Creative Commons Attribution Non-Commercial License (http://creativecommons. org/licenses/by-nc/3.0/) which permits unrestricted non-commercial use, distribution, and reproduction in any medium, provided the original work is properly cited.
TP and TF contents were slightly increased from 9.31 and 8.61 $\mathrm{mg} / \mathrm{g}$ at 0 day to 9.97 and $9.3 \mathrm{mg} / \mathrm{g}$ at 180 days, corresponding to the radical scavenging activities of 2,2-diphenyl-1-picrydrazyl, 2,4,6-azino-bis (3-ethylbenzthiazoline-6-sulphnoic acid), and hydroxyl increased from 30.91, 55.98 and $23.27 \%$ from 37.10 , 62.54 , and $30.95 \%$, respectively.

Keywords Amino acids · Antioxidant · Fatty acids · Isoflavones - Soybean leaf $\cdot$ Storage

\section{서 론}

콩(Glycine max. Merr L)은 식용작물로서 널리 재배되고 있으 며 동서양을 막론하고 1,000 여 가지의 용도로 이용되고 있는 세 계적인 식품으로 콩에 대한 다양한 연구가 진행되었다. 콩에는 단백질, 식이섬유 그 밖에 이소플라본, 사포닌, 레시틴 등 다양 한 생리활성 물질들이 존재하며 그 중 genistein 및 daidzein과 같은 이소플라본은 체내에서 대사되는 과정에서 생성되는 equol 과 같은 대사생성물에 대한 연구도 활발히 진행되고 있다[1,2]. 콩의 부산물인 콩잎은 경상도, 제주도 지역에서 한정적으로 사 용되는 식재료로써 널리 알려진 재료는 아니다. 초기 콩잎에 관 한 연구에는 콩잎 물김치 숙성 중 이화학적 특성 변화[3], 소금 농도가 콩잎 김치의 숙성에 미치는 영향[4], 키토산 첨가 콩잎 김치의 저장성 향상에 관한 연구[5] 등 콩잎을 이용한 식품의 품질에 관한 연구가 주를 이루었다. 최근에는 콩잎 및 콩잎 요 리의 이소플라본 함량 및 항산화 관련 성분 비교[6], 고지방식 
이 마우스에서 콩잎 추출물의 지방간 억제 효과[7], 수확 후 에 틸렌 및 광 처리에 의한 콩잎 중 플라보노이드 함량 변화[8], 추출 조건에 따른 콩잎 추출물의 이소플라본 함량 및 이화학적 특성[9], 젖산균 발효를 통한 콩잎 추출물의 비배당체 이소플라 본 함량 증대에 관한 연구[10] 등 항산화 활성 및 기능성 성분 에 대한 연구가 보고되고 있다. 이소플라본류, 플라본류, 플라 보놀류, 페놀성 화합물 등 총 16 종의 항산화 물질이 콩잎에 함 유되어 있다고 보고되고 있으며 그 밖에도 클로로필, 카로티노 이드, 비타민 C등의 함량이 높은 것으로 보고되고 있다[6].

에틸렌(ethylene), 지베렐린(gibberellin) 등의 식물생장조절제 (Plant growth regulation)는 천연물질 또는 합성물질로 식물의 성장과 발달을 인위적으로 조절한다. 이중 에틸렌 호르몬은 식 물에서 다양한 생리활성 나타내며, 식물의 생장을 조절하는 물 질로 식물 대사체 합성에 관여하여 이차대사산물 합성을 촉진 하는 것으로 알려져 있다[11]. 본 연구팀은 선행연구에서 에틸 렌을 처리할 경우 콩잎에서 isoflavone 함량이 급격히 증가하는 결과를 확인하였다. Daidzin, genistin, malonyldaidzin 및 malonylgenistin의 함량이 모두 증가하여 총 이소플라본 함량은 $0.2 \mathrm{mg} / \mathrm{g}$ 미만에서 에틸렌 전구체인 에테폰(ethephon) 처리 후 24시간만에 $7 \mathrm{mg} / \mathrm{g}$ 이상으로 증가하였으며, 처리 후 96시간에 약 $15 \mathrm{mg} / \mathrm{g}$ 이상으로 증가하여 일반 콩에 비해 5 배 이상의 이 소플라본 함량을 나타내었다[12].

Saio 등[13] 및 Sio와 Arisaka[14]는 고온 고습에서 1개월 동 안 콩의 저장 중 품질변화에 대해 연구하였고, $\mathrm{Sul}$ 등[15]은 저 장 온도가 콩의 질소용해도 변화, 산가, 유기산 변화, 지방산 및 아미노산 등의 변화에 미치는 영향을 연구하는 등 콩의 저장성 에 대한 조사는 몇몇 이루어져 있으나 콩잎의 저장성에 대한 연구는 수행되지 않았다. 콩잎과 같은 엽채류는 저장성이 떨어 지기 때문에 냉동, 동결건조 및 최근에는 cold-chain 방법을 이 용한 유통판매가 활발히 이루어지고 있다. 그러나 본 연구에서 사용된 고 이소플라본 함유 콩잎은 이소플라본 함량 변화를 최 소화하기 위해 수확 후 즉시 세척 및 건조하여 보관하며 이러 한 특성으로 고 이소플라본 함유 콩잎은 소비자들의 식탁에서 소비가 어려우며 대부분 건조형태로 보관하며 필요에 따라 기 능성 소재로 이용된다.

따라서 고 이소플라본 함유 콩잎은 수확 후 건조 보관하는 과정에서 기능성 성분인 이소플라본과 기타 성분에 대한 변화 를 최소화할 수 있는 저장 조건에 대한 연구가 필요하다. 본 연 구에서는 고 이소플라본 함유 콩잎을 수확 후 건조 및 분쇄하 여 저장 온도 및 기간에 따라 지방산, 아미노산, 무기질, 이소 플라본, 총 phenolics, 총 flavonoids 및 라디칼 소거활성 변화 를 분석하였다.

\section{재료 및 방법}

\section{재료, 시약 및 분석 기기}

본 연구에 사용한 고 이소플라본 함유 콩잎은 선행연구의 방법 에 따라 2019년도 남해군일대에서 재배된 것을 농업회사법인 주식회사 제이씨엔팜으로부터 건조된 상태로 공급받아 사용하 였다. 즉, 대원콩 종자를 파종 후 약 60 일(R3 생육단계: 까투리 가 맺히기 전 최대 성장 시기) 동안 재배된 콩잎에 에테폰을
$200 \mu \mathrm{g} / \mathrm{mL}$ 농도로 약액이 흐를 정도로 충분히 24시간 간격으 로 2회 살포하였다[12]. 첫 살포 후 96시간 후에 콩잎을 수확 하여 물로 깨끗이 세척 후 식품건조기 $\left(35^{\circ} \mathrm{C}\right)$ 에서 건조하였다. 습도의 영향을 최소화하기 위해 건조 시료를 공급받아 분쇄하 고 $100 \mathrm{~g}$ 씩 칭량하여 크린팩에 담은 후 크린팩을 다시 락앤락 $(20 \mathrm{~cm} \times 20 \mathrm{~cm} \times 10 \mathrm{~cm})$ 밀폐용기에 담아 준비하였다. 건조된 콩 잎이 들어있는 밀폐용기는 냉장고(TRS30MHBFA, Samsung, Korea), 저온 배양기(ThermoStable IR-250, DAIHAN Scientific, Korea) 및 건조기(WOF-W155, DAIHAN Scientific, Korea)를 사용하여 각각 $5 \pm 1,25 \pm 1$ 및 $55 \pm 1{ }^{\circ} \mathrm{C}$ 를 유지하며 60 일, 120 일 및 180 일간 저장하였으며 0 일, 60 일 및 120 일 시료는 180 일 시료와 동시 분석을 위하여 $-70{ }^{\circ} \mathrm{C}$ 보관한 후 최종 180 일 시 료와 같이 본 연구에 사용하였다. 이소플라본 표준품 중 malonylgenistin과 malonyldaidzin은 LC Laboratories (Woburn, MA, USA)에서 구입하였고, genistin과 daidzin, daidzein, gesnistein 은 Sigma-Aldrich Co. (St, Louis, MO, USA)에서 구입하였다. Folin-cioalteu reagent, diethylen glycol, 2,4,6-azino-bis (3ethylbenzthiazoline-6-sulphnoic acid) (ABTS), 2,2-diphenyl-1picrydrazyl (DPPH), thiobarbituric acid (TBA) 및 trichloroacetic acid (TCA) 역시 Sigma-Aldrich Co.에서 구입하여 사용하였다. 추출물 제조와 라디칼 소거활성 및 기기 분석 등에 사용한 유 기용매(methanol, acetonitrile, water 및 acetic acid 등)는 J.T.Baker (Philpsbug, NJ, USA)에서 구입하여 사용하였고 이 외 기타 시약은 필요에 따라서 분석용 특급 또는 1 급을 구입하 여 사용하였다.

지방산 분석은 gas chromatography (GC, Agilent 7890A system, Agilent Technologies Inc., Wilmington, DE, USA)를 사용하였 고 아미노산 분석은 자동아미노산 분석기 (L-8900, Hitachi High-Technologies Corp., Tokyo, Japan)를 사용하여 분석하였다. 무기질 분석은 liquid chromatography-inductively coupled plasma mass spectrometer (NexION 350 ICP MS, PerkinElmer Inc., Waltham, USA)를 사용하였고 이소플라본 분석은 high performance liquid chromatography (HPLC, Agilent 1200 system, Agilent Technologies Inc., Waldbronn, Germany)를 사용하여 분석하였다. 이 외 총 phenolics, 총 flavonoids 및 라 디칼 소거활성 측정은 분광광도계(UV-1800 240V, Shimadzu Corp., Kyoto, Japan)를 사용하여 측정하였다.

\section{지방산 분석}

콩잎의 지방산 함량은 Hwang 등[16]의 연구에 준하여 분석하 였다. 각각의 콩잎 분말 $1 \mathrm{~g}$ 에 $0.5 \mathrm{~N}$ 메탄올성 $\mathrm{NaOH}$ 용액 3 $\mathrm{mL}$ 를 가하여 $100{ }^{\circ} \mathrm{C}$ 에서 10 분간 가열하여 지방산과 글리세롤 가수분해하였다. 이어 삼불화붕소 $\left(\mathrm{BF}_{3}\right) 2 \mathrm{~mL}$ 를 가하여 교반 후 30 분간 다시 가열하여 지방산 메틸에스테르화를 진행하였다. 반 응 종료 후 이소옥탄 $1 \mathrm{~mL}$ 를 첨가하여 격렬히 흔든 후 방치시 켜 이소옥탄 층에 녹아 든 유지층만을 회수하여 무수아황산나 트륨과 함께 탈수한 뒤 $0.45 \mu \mathrm{m}$-membrane filter (Dismic25CS, Toyoroshikaisha, Ltd., Tokyo, Japan)로 여과하여 GC로 분석하였다. GC는 질소 및 수소 가스와 SP-2560 capillary column $(100 \mathrm{mT} \times \mathrm{T} 0.25 \mathrm{~mm}$ i.d., $0.25-\mu \mathrm{m}$ film thickness, SigmaAldrich Co., St. Louis, MO, USA) 및 flame ion detector (FID)가 장착된 것을 사용하였다. 상세 분석조건으로는 oven 초 
기 온도 $140{ }^{\circ} \mathrm{C}$ 에서 5 분간 유지 후, $180{ }^{\circ} \mathrm{C}$ 까지 1 분당 $20^{\circ} \mathrm{C}$ 만 큼 상승시켜 2 분간 유지하고 최종 $230{ }^{\circ} \mathrm{C}$ 까지 분당 $5{ }^{\circ} \mathrm{C}$ 만큼 상 승시켰으며 각각의 시료량은 $10 \mu \mathrm{L}$ 를 주입하여 35 분간 $\mathrm{FID}$ 상 에서 지방산 함량을 검출하였다.

\section{유리아미노산 분석}

유리아미노산은 Hwang 등[17]의 방법을 약간 변형하여 수행하 였다. 각각의 콩잎 시료 $0.1 \mathrm{~g}$ 을 정확히 칭량하여 시험관에 넣 고 여기에 증류수 $5 \mathrm{~mL}$ 를 가하여 균질화한 후 heating block (HB-48P, DAIHAN Scientific, Korea)을 사용하여 $60^{\circ} \mathrm{C}$ 에서 1 시간 가수분해하였다. 가수분해 후 $10 \%$ 의 5-sulfosalicylic acid dihydrate $1 \mathrm{~mL}$ 를 첨가 및 혼합하여 $4{ }^{\circ} \mathrm{C}$ 에서 2 시간 방치한 후 $15,000 \mathrm{rpm}$ 에서 3 분간 원심분리 및 syringe filter로 여과하였다. 이후 여과액은 회전식 감압농축기를 이용하여 $50{ }^{\circ} \mathrm{C}$ 온도로 감 압농축하여 $\mathrm{pH} 2.2$ lithium buffer $2 \mathrm{~mL}$ 을 가하여 용해시켜 $0.45 \mu \mathrm{m}$-membrane filter로 여과한 후 아미노산 자동분석기로 정 량 분석하였다.

\section{무기질}

무기질 분석은 $\mathrm{Kim}$ 등[18]의 무기질 분석법에 준하여 수행하였 다. 각각의 콩잎 분말 $0.5 \mathrm{~g}$ 에 $70 \%$ 질산 용액 $10 \mathrm{~mL}$ 을 첨가하 여 microwave로 분해하였다. 분해 이후 멸균증류수로 최종 50 $\mathrm{mL}$ 가 되도록 정용하여 시험 용액을 제조하였고, 나트륨은 550$600^{\circ} \mathrm{C}$ 회화로에서 회화한 후 $3 \%$ 질산 용액으로 최종 $30 \mathrm{~mL}$ 로 정용하여 시험 용액을 제조한 후 ICP-MS로 분석하였다.

\section{추출물 제조}

각각의 콩잎 분말 $1 \mathrm{~g}$ 에 $80 \%$ 주정을 $30 \mathrm{~mL}$ 가하여 상온에서 12-16시간 추출하여 원심분리 후 상층액을 $0.45 \mu \mathrm{m}$-membrane filter로 여과하여 추출물을 제조하였다. 이 추출물은 이소플라본, 총 phenolics, 총 flavonoids 및 라디칼 소거활성 측정 시료로 사용하였다.

\section{이소플라본}

이소플라본 분석은 Lee 등[19]의 연구방법에 준하여 HPLC로 분석하였다. 분석에 사용된 컬럼은 Lichrophore $100 \mathrm{RP} \mathrm{C} 18$ (LichroCART 125-4, $5 \mu \mathrm{m}, 125 \mathrm{~mm} \times 4 \mathrm{~mm}$, Merck KGaA, Darmstadt, Germany)이며 이동상 용매는 $0.2 \%$ acetic acid 함 유 HPLC 등급의 water (A용매)와 $0.2 \%$ acetic acid 함유 HPLC 등급의 acetonitrile (B용매)로 분석하였다. 각 이동상 용 매의 조건은 A 용매 기준으로 $100 \%$ (0분), $90 \%$ (15분), $80 \%$ (25분), $75 \%$ (35분), $65 \%$ (45분) 및 $65 \%$ (50분)로 설정하였다. 시료 주입량은 $20 \mu \mathrm{L}$ 로 설정하였고 이동상 속도는 $30^{\circ} \mathrm{C}$ 에서 분당 $1 \mathrm{~mL}$ 의 유속으로 diode array detector를 통과하여 254 $\mathrm{nm}$ 에서 검출하였다.

\section{총 phenolics 및 총 flavonoids 분석}

총 phenolics 함량은 Folin Denis법[20]으로 측정하였다. 추출물 $0.5 \mathrm{~mL}$ 에 $25 \% \quad \mathrm{Na}_{2} \mathrm{CO}_{3}$ 용액 $0.5 \mathrm{~mL}$ 를 가하여 3 분간 정치시킨 뒤 여기에 folin-ciocalteu phenol 시약 $0.25 \mathrm{~mL}$ 를 첨가하여 $30^{\circ} \mathrm{C}$ 에서 1 시간 동안 반응시켜 $750 \mathrm{~nm}$ 에서 흡광도를 측정하였 다. 이때 총 phenolics 함량은 gallic acid를 이용하여 작성한
표준곡선으로부터 함량을 구하였다.

총 flavonoids 함량은 Lee 등[21]의 방법에 준하여 측정하였 다. 추출물 $0.5 \mathrm{~mL}$ 를 시험관 분주한 후 여기에 diethylene glycol $1 \mathrm{~mL}$ 및 $1 \mathrm{~N}-\mathrm{NaOH} 0.01 \mathrm{~mL}$ 를 가하여 $37^{\circ} \mathrm{C}$ 항온수조 에서 1 시간 반응시켜 $420 \mathrm{~nm}$ 에서 흡광도를 측정하였다. 이때 총 flavonoids 함량은 rutin을 이용하여 작성한 표준곡선으로부 터 함량을 구하였다.

\section{항산화 활성}

$\mathrm{DPPH}$ 라디칼 소거활성은 Hwang 등[22]의 방법에 준하여 측정 하였다. $1.5 \times 10^{-4} \mathrm{M} \mathrm{DPPH}$ 용액 $0.8 \mathrm{~mL}$ 에 추출액 $0.2 \mathrm{~mL}$ 를 가 한 후 암실에서 30 분 반응시켜 $525 \mathrm{~nm}$ 에서 흡광도를 측정하였 다. 음성 대조구는 시료 대신에 추출용매를 취하여 실험하였다. $\mathrm{ABTS}$ 라디칼 소거활성은 $7 \mathrm{mM} \mathrm{ABTS}$ 용액과 $2.45 \mathrm{mM}$ potassium persulphate를 1:1로 혼합하여 암실에서 12-16시간 방 치시켜 ABTS 양이온을 형성시켰다. 양이온이 형성된 ABTS 용 액과 메탄올을 희석시켜 $732 \mathrm{~nm}$ 에서 흡광도 값이 $0.7 \pm 0.02$ 로 제조된 $\mathrm{ABTS}+$ 용액 $0.9 \mathrm{~mL}$ 에 추출물 $0.1 \mathrm{~mL}$ 을 가하여 3 분후 $732 \mathrm{~nm}$ 에서 흡광도를 측정하였다[20]. 음성 대조구는 시료 대신 에 추출 용매를 취하여 실험하였다.

Hydroxyl 라디칼 소거활성은 시험관에 $10 \mathrm{mM} \mathrm{FeSO} 4$-EDTA 용액 $0.2 \mathrm{~mL}, 10 \mathrm{mM}$ 2-deoxylribose $0.2 \mathrm{~mL}$, 추출물 $1.2 \mathrm{~mL}$ 와 $10 \mathrm{mM} \mathrm{H} \mathrm{H}_{2} \quad 0.4 \mathrm{~mL}$ 를 순차적으로 첨가 하고 $37^{\circ} \mathrm{C}$ 에서 4 시간 반응시켰다. 반응 후 여기에 $\mathrm{HPLC}$ water에 용해된 $1 \% \mathrm{TBA}$ 와 $2.8 \% \mathrm{TCA}$ 를 각각 $1 \mathrm{~mL}$ 씩 가한 후 $100{ }^{\circ} \mathrm{C}$ 끓는 물에서 20 분 간 발색 시키고 냉각 후 $525 \mathrm{~nm}$ 에서 흡광도를 측정하였다[23]. 음성 대조구는 시료 대신에 PBS 취하여 실험하였다. 모든 항 산화 활성은 실험구와 음성대조구의 흡광도 차이를 $\%$ 로 나타 내었으며 아래와 같은 식에 의해 산출하였다.

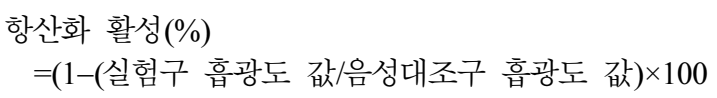

\section{통계분석}

통계처리 실험 결과는 SPSS 12.0 package를 사용하여 분산 분 석을 수행하였고 평균 \pm 표준편차로 나타내었다. 각 시료 분석 결과에 대한 유의성 검정은 분산 분석 후 $p<0.05$ 수준에서 Duncan's multiple range test를 실시하였다

\section{결과 및 고찰}

\section{저장 온도 및 기간에 따른 지방산 조성 변화}

콩잎의 저장 온도 및 기간별 지방산 함량을 분석한 결과 Table 1 과 같았다. 저장 0 일 포화지방산 중 palmitic acid는 319.2 $\mathrm{mg} / 100 \mathrm{~g}$ 으로 가장 높았으며 stearic acid는 $146.4 \mathrm{mg} / 100 \mathrm{~g}$ 으로 두 번째로 많았으며 myristic acid는 $8.4 \mathrm{mg} / 100 \mathrm{~g}$ 으로 가장 낮 은 함량을 나타내었다. 저장 0 일째 불포화 지방산 중 myristoleic acid, ecosadienoic acid, eicodatrienoic acid 및 nervonic acid 는 검출되지 않았으며 $\alpha$-linolenic은 $460.3 \mathrm{mg} / 100 \mathrm{~g}$ 으로 가장 높았으며 linoleic acid는 $235.7 \mathrm{mg} / 100 \mathrm{~g}$ 으로 두 번째로 높은 함량을 나타내었다. 저장 60 일에 저장 온도별 콩잎 시료의 포 화 지방산 중 myristic acid는 5,25 및 $55^{\circ} \mathrm{C}$ 각각 $10.9,10.0$ 
Table 1 Change of fatty acid contents in soybean leaf containing high isoflavone according to storage temperatures and periods

\begin{tabular}{|c|c|c|c|c|c|c|c|c|c|c|}
\hline \multirow{3}{*}{$\begin{array}{c}\text { Contents }{ }^{1)} \\
(\mathrm{mg} / 100 \text { g d.w. })\end{array}$} & \multicolumn{10}{|c|}{ Storage periods/Temperature } \\
\hline & \multirow{2}{*}{0 day } & \multicolumn{3}{|c|}{60 day } & \multicolumn{3}{|c|}{120 day } & \multicolumn{3}{|c|}{180 day } \\
\hline & & $5^{\circ} \mathrm{C}$ & $25^{\circ} \mathrm{C}$ & $55^{\circ} \mathrm{C}$ & $5{ }^{\circ} \mathrm{C}$ & $25^{\circ} \mathrm{C}$ & $55^{\circ} \mathrm{C}$ & $5^{\circ} \mathrm{C}$ & $25^{\circ} \mathrm{C}$ & $55^{\circ} \mathrm{C}$ \\
\hline \multicolumn{11}{|l|}{ Saturated fatty acids (SFA) } \\
\hline Myristic acid (C14:0) & $8.4 \pm 0.08 b$ & $10.9 \pm 0.22 \mathrm{ab}$ & $10.0 \pm 0.1 \mathrm{ab}$ & $11.1 \pm 0.11 \mathrm{a}$ & $11.5 \pm 0.23 \mathrm{a}$ & $10.4 \pm 0.3 \mathrm{ab}$ & $12.3 \pm 0.12 \mathrm{a}$ & $10.0 \pm 0.10 \mathrm{ab}$ & $11.5 \pm 0.12 \mathrm{a}$ & $10.1 \pm 0.20 \mathrm{ab}$ \\
\hline Palmitic acid (C16:0) & $319.2 \pm 3.19 \mathrm{ab}$ & $309.6 \pm 3.1 \mathrm{ab}$ & $286.6 \pm 5.72 b$ & $294.1 \pm 5.88 b$ & $295.6 \pm 8.87 \mathrm{~b}$ & $297.5 \pm 2.98 b$ & $291.6 \pm 5.83 b$ & $319.1 \pm 3.19 \mathrm{ab}$ & $349.1 \pm 3.49 \mathrm{a}$ & $314.1 \pm 6.28 \mathrm{ab}$ \\
\hline Stearic acid $(\mathrm{C} 18: 0)$ & $146.4 \pm 1.46 \mathrm{ab}$ & $129.5 \pm 2.6 b$ & $116.8 \pm 1.17 \mathrm{~b}$ & $115.6 \pm 4.62 b$ & $130.9 \pm 1.31 \mathrm{~b}$ & $131.2 \pm 2.62 b$ & $128.4 \pm 1.28 \mathrm{~b}$ & $163.8 \pm 1.64 \mathrm{a}$ & $175.5 \pm 1.76 \mathrm{a}$ & $154.4 \pm 4.63 \mathrm{ab}$ \\
\hline Arachidic acid (C20:0) & $15.1 \pm 0.3 \mathrm{a}$ & $10.7 \pm 0.11 \mathrm{ab}$ & $10.4 \pm 0.20 \mathrm{ab}$ & $10.6 \pm 0.53 \mathrm{ab}$ & $9.8 \pm 0.29 \mathrm{~b}$ & $10.0 \pm 0.30 \mathrm{ab}$ & $9.8 \pm 0.12 b$ & $10.5 \pm 0.22 \mathrm{ab}$ & $10.4 \pm 0.30 \mathrm{ab}$ & $10.1 \pm 0.30 \mathrm{ab}$ \\
\hline Behenic aicd (C22:0) & $21.8 \pm 0.44 \mathrm{a}$ & $14.8 \pm 0.26 \mathrm{ab}$ & $13.4 \pm 0.26 \mathrm{ab}$ & $14.4 \pm 0.14 \mathrm{ab}$ & $12.6 \pm 0.13 b$ & $12.8 \pm 0.13 b$ & $11.7 \pm 0.15 \mathrm{~b}$ & $12.3 \pm 0.24 \mathrm{~b}$ & $12.1 \pm 0.24 b$ & $12.3 \pm 0.49 \mathrm{~b}$ \\
\hline Lignoceric acid (C24:0) & $21.7 \pm 0.22 \mathrm{a}$ & $15.9 \pm 0.16 \mathrm{ab}$ & $16.7 \pm 0.17 \mathrm{ab}$ & $15.5 \pm 0.31 \mathrm{ab}$ & $15.4 \pm 0.62 \mathrm{ab}$ & $15.5 \pm 0.16 \mathrm{ab}$ & $14.8 \pm 0.21 \mathrm{~b}$ & $14.8 \pm 0.45 b$ & $14.4 \pm 0.28 b$ & $15.3 \pm 0.15 \mathrm{ab}$ \\
\hline Total & 532.6 & 491.4 & 453.9 & 461.3 & 475.8 & 477.4 & 468.6 & 530.5 & 573 & 516.3 \\
\hline \multicolumn{11}{|l|}{ Unsaturated fatty acids (USFA) } \\
\hline Myristoleic acid (C14:1) & $\mathrm{nd}^{2)}$ & $3.5 \pm 0.04 \mathrm{ab}$ & nd & $5.2 \pm 0.10 \mathrm{a}$ & $2.7 \pm 0.03 \mathrm{a}$ & $1.9 \pm 0.02 \mathrm{ab}$ & nd & nd & nd & nd \\
\hline Palmitoleic acid (C16:1) & $4.3 \pm 0.09 \mathrm{~b}$ & $1.7 \pm 0.04 \mathrm{~b}$ & nd & $18.3 \pm 0.37 \mathrm{a}$ & $6.1 \pm 0.18 \mathrm{ab}$ & $2.3 \pm 0.04 \mathrm{~b}$ & $2.2 \pm 0.04 \mathrm{~b}$ & $3.9 \pm 0.04 \mathrm{~b}$ & $5.7 \pm 0.06 \mathrm{ab}$ & $16.8+0.50 \mathrm{a}$ \\
\hline Oleic acid (C18:1c) & $88.1 \pm 0.88 \mathrm{a}$ & $41.1 \pm 0.41 \mathrm{ab}$ & $38.8 \pm 0.39 \mathrm{~b}$ & $41.2 \pm 0.41 \mathrm{ab}$ & $54.0 \pm 0.54 \mathrm{ab}$ & $40.7 \pm 0.41 \mathrm{ab}$ & $40.7 \pm 1.22 \mathrm{ab}$ & $41.4 \pm 0.83 \mathrm{ab}$ & $90.8 \pm 1.82 \mathrm{a}$ & $37.8 \pm 0.76 \mathrm{~b}$ \\
\hline Linoleic acid (C18:2c) & $235.7 \pm 7.07 \mathrm{a}$ & $161.6 \pm 1.62 \mathrm{ab}$ & $161.8 \pm 3.24 \mathrm{ab}$ & $159.1 \pm 4.77 \mathrm{ab}$ & $155.7 \pm 1.56 \mathrm{ab}$ & $162.2 \pm 1.62 \mathrm{ab}$ & $136.1 \pm 1.36 \mathrm{~b}$ & $146.8 \pm 1.47 \mathrm{~b}$ & $181.8 \pm 2.36 \mathrm{a}$ & $134.1 \pm 2.68 \mathrm{~b}$ \\
\hline$\gamma$-Linolenic acid (C18:3n6) & $6.0 \pm 0.12 \mathrm{a}$ & $4.4 \pm 0.12 \mathrm{ab}$ & $4.4 \pm 0.13 \mathrm{ab}$ & $3.8 \pm 0.08 \mathrm{~b}$ & $4.0 \pm 0.12 \mathrm{ab}$ & $3.9 \pm 0.12 b$ & $3.2 \pm 0.10 \mathrm{~b}$ & $3.6 \pm 0.11 \mathrm{~b}$ & $4.1 \pm 0.04 \mathrm{ab}$ & $3.1 \pm 0.06 \mathrm{~b}$ \\
\hline$\alpha$-Linolenic (C18:3n3) & $460.3 \pm 9.21 \mathrm{ab}$ & $535.0 \pm 5.35 \mathrm{a}$ & $546.8 \pm 10.94 \mathrm{a}$ & $483.4 \pm 4.83 \mathrm{ab}$ & $529.4 \pm 5.29 \mathrm{a}$ & $538.9 \pm 5.39 \mathrm{a}$ & $391.3 \pm 3.91 b$ & $465.9 \pm 4.66 \mathrm{ab}$ & $507.2 \pm 10.14 \mathrm{a}$ & $384.2 \pm 3.84 \mathrm{~b}$ \\
\hline Eicosenic acid (C20:1) & $3.8 \pm 0.11 \mathrm{a}$ & $2.0 \pm 0.06 \mathrm{~b}$ & $2.1 \pm 0.02 b$ & $2.0 \pm 0.06 \mathrm{~b}$ & nd & nd & $2.5 \pm 0.05 \mathrm{ab}$ & nd & $3.0 \pm 0.12 \mathrm{ab}$ & nd \\
\hline Ecosadienoic acid (C20:2) & nd & $2.1 \pm 0.08 \mathrm{~b}$ & nd & $6.0 \pm 0.12 \mathrm{ab}$ & $7.2 \pm 0.07 \mathrm{a}$ & $6.4 \pm 0.06 \mathrm{ab}$ & $7.0 \pm 0.14 \mathrm{a}$ & $7.0 \pm 0.14 \mathrm{a}$ & nd & $5.9 \pm 0.12 \mathrm{ab}$ \\
\hline Eicodatrienoic acid (C20:3n3) & nd & nd & $1.7 \pm 0.05 \mathrm{a}$ & $1.5 \pm 0.03 \mathrm{a}$ & nd & nd & nd & nd & nd & nd \\
\hline Arachidonic acid (C20:4n6) & $9.0 \pm 0.36 \mathrm{a}$ & $5.6 \pm 0.06 \mathrm{ab}$ & $5.9 \pm 0.06 \mathrm{ab}$ & $3.8 \pm 0.11 \mathrm{~b}$ & $5.3 \pm 0.15 \mathrm{ab}$ & $5.7 \pm 0.18 \mathrm{ab}$ & $5.5 \pm 0.11 \mathrm{ab}$ & $5.4 \pm 0.16 \mathrm{ab}$ & $5.3 \pm 0.11 \mathrm{ab}$ & $5.5 \pm 0.17 \mathrm{ab}$ \\
\hline Nervonic acid (C24:1n9) & nd & nd & nd & nd & nd & nd & nd & nd & nd & $2.4 \pm 0.05$ \\
\hline Total & 807.2 & 757 & 761.5 & 724.3 & 764.4 & 762 & 588.5 & 674 & 797.9 & 589.8 \\
\hline Total fatty acids & 1339.8 & 1248.4 & 1215.4 & 1185.6 & 1240.2 & 1239.4 & 1057.1 & 1204.5 & 1370.9 & 1106.1 \\
\hline \multicolumn{11}{|c|}{$\begin{array}{l}{ }^{1)} \text { All values are presented as the mean of triplicate determination. All values within a column with different superscript letters are significantly from each other at } p<0.05 \text { by Duncan's multiple range } \\
\text { test } \\
{ }^{2)} \text { nd: not detected }\end{array}$} \\
\hline
\end{tabular}


Table 2 Change of free amino acid contents in soybean leaf containing high isoflavone according to storage temperatures and periods

\begin{tabular}{|c|c|c|c|c|c|c|c|c|c|c|}
\hline \multirow{3}{*}{$\begin{array}{l}\text { Contents }{ }^{1)}(\mathrm{mg} / 100 \mathrm{~g} \\
\text { d.w. })\end{array}$} & \multicolumn{10}{|c|}{ Storage periods / Temperature } \\
\hline & \multirow{2}{*}{0 day } & \multicolumn{3}{|c|}{60 day } & \multicolumn{3}{|c|}{120 day } & \multicolumn{3}{|c|}{180 day } \\
\hline & & 5 & 25 & 55 & 5 & 25 & 55 & 5 & 25 & 55 \\
\hline \multicolumn{11}{|c|}{ Non-essential amino acids (NEAA) } \\
\hline Urea & $129.23 \pm 1.29 b c$ & $217.48 \pm 2.17 \mathrm{a}$ & $185.80 \pm 5.57 \mathrm{ab}$ & $77.85 \pm 3.11 \mathrm{c}$ & $210.06 \pm 2.10 \mathrm{a}$ & $174.44 \pm 1.74 \mathrm{ab}$ & $146.78 \pm 5.87 b$ & $231.65 \pm 4.63 \mathrm{a}$ & $227.20 \pm 6.82 \mathrm{a}$ & $132.43 \pm 2.65 b c$ \\
\hline Proline & $103.98 \pm 2.08 \mathrm{ab}$ & $128.93 \pm 2.58 \mathrm{a}$ & $107.13 \pm 2.14 \mathrm{ab}$ & $68.64 \pm 0.69 \mathrm{c}$ & $122.50 \pm 2.45 \mathrm{a}$ & $101.92 \pm 2.04 \mathrm{ab}$ & $81.89 \pm 2.46 \mathrm{c}$ & $135.07 \pm 6.75 \mathrm{a}$ & $130.49 \pm 2.61 \mathrm{a}$ & $121.82 \pm 4.87 \mathrm{a}$ \\
\hline Hydroxyproline & $\mathrm{nd}^{2)}$ & $0.70 \pm 0.01 \mathrm{ab}$ & $1.11 \pm 0.04 \mathrm{a}$ & nd & nd & nd & $1.04 \pm 0.04 \mathrm{a}$ & $0.60 \pm 0.02 \mathrm{ab}$ & $0.27 \pm 0.01 \mathrm{~b}$ & $0.84 \pm 0.02 \mathrm{ab}$ \\
\hline Aspartic acid & $102.42 \pm 4.10 \mathrm{bc}$ & $114.08 \pm 3.42 b c$ & $111.22 \pm 2.22 \mathrm{bc}$ & $78.64 \pm 1.57 \mathrm{c}$ & $117.83 \pm 3.53 \mathrm{bc}$ & $127.24 \pm 3.82 b$ & $108.43 \pm 2.17 \mathrm{bc}$ & $147.22 \pm 1.47 \mathrm{ab}$ & $144.30 \pm 1.44 \mathrm{ab}$ & $162.08 \pm 6.48 \mathrm{a}$ \\
\hline Serine & $31.67 \pm 0.32 \mathrm{ab}$ & $39.73 \pm 1.59 a$ & $33.85 \pm 1.35 \mathrm{ab}$ & $22.07 \pm 0.88 \mathrm{~b}$ & $38.38 \pm 0.77 \mathrm{a}$ & $33.24 \pm 0.66 \mathrm{ab}$ & $26.63 \pm 0.80 \mathrm{~b}$ & $42.00 \pm 1.26 \mathrm{a}$ & $40.60 \pm 1.62 \mathrm{a}$ & $39.15 \pm 0.78 \mathrm{a}$ \\
\hline Aspartic acid - $\mathrm{NH}_{2}$ & $326.86 \pm 9.81 \mathrm{ab}$ & $425.95 \pm 12.78 \mathrm{a}$ & $338.88 \pm 10.17 \mathrm{ab}$ & $227.85 \pm 6.84 b$ & $396.89 \pm 11.91 \mathrm{ab}$ & $308.29 \pm 15.41 \mathrm{ab}$ & $252.68 \pm 10.11 \mathrm{~b}$ & $409.97 \pm 8.20 \mathrm{a}$ & $399.78 \pm 8.00 \mathrm{ab}$ & $380.33 \pm 15.21 \mathrm{ab}$ \\
\hline Glutamic acid & $48.91 \pm 0.98 \mathrm{ab}$ & $68.80 \pm 1.38 \mathrm{a}$ & $52.35 \pm 1.05 \mathrm{ab}$ & $35.76 \pm 0.72 b$ & $58.55 \pm 1.17 \mathrm{ab}$ & $51.54 \pm 1.03 \mathrm{ab}$ & $43.84 \pm 0.88 \mathrm{ab}$ & $64.47 \pm 0.64 \mathrm{a}$ & $61.67 \pm 3.08 \mathrm{a}$ & $63.26 \pm 1.27 \mathrm{a}$ \\
\hline Sarcosine & $0.87 \pm 0.03 \mathrm{~b}$ & $2.25 \pm 0.07 \mathrm{a}$ & $0.67 \pm 0.03 b$ & nd & $0.92 \pm 0.03 \mathrm{~b}$ & $0.85 \pm 0.03 \mathrm{~b}$ & nd & $1.21 \pm 0.04 \mathrm{ab}$ & $1.15 \pm 0.02 \mathrm{ab}$ & $0.89 \pm 0.04 \mathrm{~b}$ \\
\hline Aminoadipic acid & $10.60 \pm 0.21 \mathrm{~b}$ & $13.37 \pm 0.27 \mathrm{a}$ & $1.17 \pm 0.01 \mathrm{c}$ & $6.70 \pm 0.20 \mathrm{bc}$ & $12.63 \pm 0.25 \mathrm{ab}$ & $11.49 \pm 0.23 \mathrm{ab}$ & $9.12 \pm 0.09 \mathrm{bc}$ & $13.05 \pm 0.52 \mathrm{a}$ & $12.39 \pm 0.50 \mathrm{ab}$ & $13.33 \pm 0.27 \mathrm{a}$ \\
\hline Glycine & $8.17 \pm 0.33 b$ & $10.02 \pm 0.30 \mathrm{ab}$ & $8.39 \pm 0.17 b$ & $10.53 \pm 0.53 \mathrm{ab}$ & $9.71 \pm 0.29 \mathrm{ab}$ & $8.56 \pm 0.26 \mathrm{~b}$ & $11.76 \pm 0.47 \mathrm{ab}$ & $10.46 \pm 0.21 \mathrm{ab}$ & $10.17 \pm 0.20 \mathrm{ab}$ & $17.37 \pm 0.69 \mathrm{a}$ \\
\hline Alanine & $46.20 \pm 0.92 \mathrm{ab}$ & $56.89 \pm 2.28 \mathrm{a}$ & $48.05 \pm 1.92 \mathrm{ab}$ & $33.54 \pm 0.67 b$ & $54.56 \pm 1.09 \mathrm{a}$ & $46.81 \pm 1.87 \mathrm{ab}$ & $39.59 \pm 1.19 b$ & $58.94 \pm 2.36 \mathrm{a}$ & $55.80 \pm 2.23 \mathrm{a}$ & $56.83 \pm 1.14 \mathrm{a}$ \\
\hline Citrulline & $1.93 \pm 0.10 \mathrm{ab}$ & $2.68 \pm 0.05 \mathrm{a}$ & $2.27 \pm 0.05 \mathrm{a}$ & $1.50 \pm 0.05 \mathrm{~b}$ & $2.36 \pm 0.07 \mathrm{a}$ & $2.25 \pm 0.05 \mathrm{a}$ & $1.83 \pm 0.04 \mathrm{ab}$ & $2.06 \pm 0.04 \mathrm{a}$ & $1.76 \pm 0.05 \mathrm{ab}$ & $1.61 \pm 0.06 \mathrm{~b}$ \\
\hline$\alpha$-aminobutyric acid & $15.25 \pm 0.31 \mathrm{ab}$ & $19.77 \pm 0.40 \mathrm{a}$ & $15.82 \pm 0.47 \mathrm{ab}$ & $11.09 \pm 0.11 b c$ & $18.17 \pm 0.36 \mathrm{a}$ & $16.35 \pm 0.65 \mathrm{ab}$ & $13.19 \pm 0.40 \mathrm{bc}$ & $20.91 \pm 0.63 a$ & nd & $1.96 \pm 0.04 \mathrm{c}$ \\
\hline Cystine & $9.92 \pm 0.10 \mathrm{ab}$ & $12.84 \pm 0.39 \mathrm{a}$ & $10.33 \pm 0.21 \mathrm{ab}$ & $8.08 \pm 0.32 b$ & $11.22 \pm 0.45 \mathrm{ab}$ & $9.74 \pm 0.10 \mathrm{ab}$ & $9.39 \pm 0.19 \mathrm{ab}$ & $12.05 \pm 0.60 \mathrm{a}$ & $11.71 \pm 0.47 \mathrm{ab}$ & $11.86 \pm 0.47 \mathrm{ab}$ \\
\hline Tyrosine & $20.45 \pm 0.61 \mathrm{ab}$ & $25.21 \pm 1.01 \mathrm{a}$ & $21.43 \pm 0.64 \mathrm{ab}$ & $14.88 \pm 0.45 b$ & $24.00 \pm 0.24 \mathrm{a}$ & $21.09 \pm 0.84 \mathrm{ab}$ & $17.83 \pm 0.71 \mathrm{~b}$ & $26.47 \pm 0.53 \mathrm{a}$ & $24.78 \pm 0.50 \mathrm{a}$ & $24.53 \pm 0.49 \mathrm{a}$ \\
\hline$\beta$-alanine & $13.66 \pm 0.68 \mathrm{ab}$ & $16.63 \pm 0.50 \mathrm{a}$ & $14.32 \pm 0.29 \mathrm{ab}$ & $10.04 \pm 0.20 \mathrm{~b}$ & $16.14 \pm 0.65 \mathrm{a}$ & $14.20 \pm 0.28 \mathrm{ab}$ & $11.34 \pm 0.34 \mathrm{~b}$ & $17.19 \pm 0.52 \mathrm{a}$ & $15.77 \pm 0.63 \mathrm{ab}$ & $15.18 \pm 0.61 \mathrm{ab}$ \\
\hline$\beta$-aminoisobutyric acid & $11.57 \pm 0.35 \mathrm{ab}$ & $13.36 \pm 0.13 \mathrm{a}$ & $12.25 \pm 0.49 \mathrm{ab}$ & $9.30 \pm 0.37 b$ & $13.31 \pm 0.27 \mathrm{a}$ & $12.93 \pm 0.39 \mathrm{ab}$ & $10.29 \pm 0.41 \mathrm{ab}$ & $14.25 \pm 0.29 \mathrm{a}$ & $13.02 \pm 0.26 \mathrm{a}$ & $11.89 \pm 0.24 \mathrm{ab}$ \\
\hline$\gamma$-aminobutyric acid & $107.27 \pm 5.36 \mathrm{~b}$ & $133.49 \pm 2.67 \mathrm{a}$ & $112.95 \pm 2.26 \mathrm{~b}$ & $68.45 \pm 1.37 \mathrm{c}$ & $128.29 \pm 3.85 \mathrm{ab}$ & $110.24 \pm 4.41 \mathrm{~b}$ & $82.02 \pm 1.64 \mathrm{bc}$ & $139.74 \pm 4.19 \mathrm{a}$ & $132.66 \pm 5.31 \mathrm{a}$ & $113.41 \pm 3.40 \mathrm{~b}$ \\
\hline Aminoethanol & $4.24 \pm 0.04 \mathrm{ab}$ & $5.38 \pm 0.16 \mathrm{a}$ & nd & $1.93 \pm 0.02 \mathrm{~b}$ & $5.33 \pm 0.11 \mathrm{a}$ & $4.59 \pm 0.09 \mathrm{ab}$ & $2.42 \pm 0.10 \mathrm{ab}$ & $5.87 \pm 0.29 \mathrm{a}$ & $5.38 \pm 0.11 \mathrm{a}$ & $3.36 \pm 0.13 \mathrm{ab}$ \\
\hline Hydroxyproline & nd & $6.68 \pm 0.13 \mathrm{a}$ & nd & $5.96 \pm 0.18 \mathrm{ab}$ & nd & $6.85 \pm 0.27 \mathrm{a}$ & nd & nd & $4.70 \pm 0.14 b$ & nd \\
\hline Ornithine & $1.33 \pm 0.01 \mathrm{ab}$ & $1.71 \pm 0.05 \mathrm{a}$ & $1.46 \pm 0.03 \mathrm{ab}$ & $0.31 \pm 0.02 \mathrm{~b}$ & $1.67 \pm 0.05 \mathrm{a}$ & $1.55 \pm 0.05 \mathrm{ab}$ & $0.53 \pm 0.02 b$ & $0.89 \pm 0.01 \mathrm{ab}$ & $0.97 \pm 0.04 \mathrm{ab}$ & $1.04 \pm 0.03 \mathrm{ab}$ \\
\hline Arginine & $86.50 \pm 2.60 \mathrm{~b}$ & $109.82 \pm 2.20 \mathrm{ab}$ & $93.72 \pm 2.81 \mathrm{ab}$ & $61.86 \pm 0.62 \mathrm{c}$ & $103.05 \pm 5.15 \mathrm{ab}$ & $91.04 \pm 2.73 \mathrm{ab}$ & $76.67 \pm 3.07 \mathrm{bc}$ & $117.24 \pm 3.52 \mathrm{a}$ & $107.69 \pm 3.23 \mathrm{ab}$ & $115.82 \pm 4.63 \mathrm{a}$ \\
\hline Total & 1081.03 & 1425.77 & 1173.17 & 754.98 & 1345.57 & 1155.21 & 947.27 & 1471.31 & 1402.26 & 1288.99 \\
\hline
\end{tabular}


Table 3 Change of mineral contents in soybean leaf containing high isoflavone according to storage temperatures and periods

\begin{tabular}{|c|c|c|c|c|c|c|c|c|c|c|}
\hline \multirow{3}{*}{$\begin{array}{c}\text { Contents }^{1)}(\mathrm{mg} / 100 \mathrm{~g} \\
\text { d.w. })\end{array}$} & \multicolumn{10}{|c|}{ Storage periods / Temperature } \\
\hline & \multirow{2}{*}{0 day } & \multicolumn{3}{|c|}{60 day } & \multicolumn{3}{|c|}{120 day } & \multicolumn{3}{|c|}{180 day } \\
\hline & & 5 & 25 & 55 & 5 & 25 & 55 & 5 & 25 & 55 \\
\hline Phosphorus (P) & $2.87 \pm 0.03 \mathrm{ab}$ & $3.03 \pm 0.06 \mathrm{ab}$ & $3.03 \pm 0.030 \mathrm{ab}$ & $2.99 \pm 0.06 \mathrm{ab}$ & $2.76 \pm 0.06 \mathrm{~b}$ & $2.86 \pm 0.09 \mathrm{ab}$ & $3.05 \pm 0.06 \mathrm{ab}$ & $2.77 \pm 0.11 \mathrm{~b}$ & $2.77 \pm 0.08 \mathrm{~b}$ & $3.39 \pm 0.07 \mathrm{a}$ \\
\hline Kalium (K) & $23.16 \pm 0.4 \mathrm{ab}$ & $25.24 \pm 0.51 \mathrm{ab}$ & $24.76 \pm 0.50 \mathrm{ab}$ & $24.32 \pm 0.97 \mathrm{ab}$ & $23.13 \pm 0.93 \mathrm{ab}$ & $23.00 \pm 0.92 \mathrm{ab}$ & $25.69 \pm 0.77 \mathrm{ab}$ & $22.58 \pm 0.90 \mathrm{~b}$ & $22.76 \pm 0.68 b$ & $28.34 \pm 0.57 \mathrm{a}$ \\
\hline Calcium (Ca) & $19.00 \pm 0.8 \mathrm{ab}$ & $19.64 \pm 0.59 \mathrm{ab}$ & $19.77 \pm 0.59 \mathrm{ab}$ & $19.44 \pm 0.19 \mathrm{ab}$ & $17.92 \pm 0.18 \mathrm{~b}$ & $18.68 \pm 0.37 \mathrm{ab}$ & $19.60 \pm 0.78 \mathrm{ab}$ & $18.30 \pm 0.37 \mathrm{ab}$ & $18.67 \pm 0.19 \mathrm{ab}$ & $21.79 \pm 0.87 \mathrm{a}$ \\
\hline Magnesium (Mg) & $2.89 \pm 0.02 \mathrm{ab}$ & $2.99 \pm 0.12 \mathrm{ab}$ & $3.02 \pm 0.06 \mathrm{ab}$ & $2.96 \pm 0.09 \mathrm{ab}$ & $2.73 \pm 0.11 \mathrm{~b}$ & $2.83 \pm 0.11 \mathrm{ab}$ & $3.02 \pm 0.06 \mathrm{ab}$ & $2.79 \pm 0.08 \mathrm{~b}$ & $2.83 \pm 0.08 \mathrm{ab}$ & $3.36 \pm 0.17 \mathrm{a}$ \\
\hline $\operatorname{Zinc}(\mathrm{Zn})$ & $0.04 \pm 0.00 \mathrm{a}$ & $0.04 \pm 0.00 \mathrm{a}$ & $0.04 \pm 0.00 \mathrm{a}$ & $0.04 \pm 0.00 \mathrm{a}$ & $0.04 \pm 0.00 \mathrm{a}$ & $0.04 \pm 0.00 \mathrm{a}$ & $0.04 \pm 0.00 \mathrm{a}$ & $0.04 \pm 0.00 \mathrm{a}$ & $0.04 \pm 0.00 \mathrm{a}$ & $0.04 \pm 0.00 \mathrm{a}$ \\
\hline Manganese (Mn) & $0.06 \pm 0.00 \mathrm{~b}$ & $0.06 \pm 0.00 \mathrm{~b}$ & $0.06 \pm 0.00 \mathrm{~b}$ & $0.06 \pm 0.00 \mathrm{~b}$ & $0.06 \pm 0.00 \mathrm{~b}$ & $0.06 \pm 0.00 \mathrm{~b}$ & $0.06 \pm 0.00 \mathrm{~b}$ & $0.06 \pm 0.00 \mathrm{~b}$ & $0.06 \pm 0.00 \mathrm{~b}$ & $0.07 \pm 0.00 \mathrm{a}$ \\
\hline Aluminium (Al) & $0.10 \pm 0.00 \mathrm{ab}$ & $0.10 \pm 0.00 \mathrm{ab}$ & $0.10 \pm 0.00 \mathrm{ab}$ & $0.11 \pm 0.00 \mathrm{ab}$ & $0.10 \pm 0.00 \mathrm{ab}$ & $0.09 \pm 0.00 \mathrm{~b}$ & $0.13 \pm 0.01 \mathrm{a}$ & $0.10 \pm 0.00 \mathrm{ab}$ & $0.10 \pm 0.00 \mathrm{ab}$ & $0.13 \pm 0.01 \mathrm{a}$ \\
\hline Boron (B) & $0.04 \pm 0.00 \mathrm{ab}$ & $0.05 \pm 0.00 \mathrm{ab}$ & $0.04 \pm 0.00 \mathrm{ab}$ & $0.04 \pm 0.00 \mathrm{ab}$ & $0.05 \pm 0.00 \mathrm{ab}$ & $0.02 \pm 0.00 \mathrm{~b}$ & $0.07 \pm 0.00 \mathrm{a}$ & $0.04 \pm 0.00 \mathrm{ab}$ & $0.02 \pm 0.00 \mathrm{~b}$ & $0.06 \pm 0.00 \mathrm{ab}$ \\
\hline Sodium (Na) & $0.39 \pm 0.01 \mathrm{ab}$ & $0.18 \pm 0.01 \mathrm{bc}$ & $0.26 \pm 0.01 \mathrm{~b}$ & $0.36 \pm 0.01 \mathrm{a}$ & $0.27 \pm 0.01 \mathrm{~b}$ & $0.10 \pm .0 .01 \mathrm{c}$ & $0.54 \pm 0.01 \mathrm{a}$ & $0.38 \pm 0.01 \mathrm{ab}$ & $0.13 \pm 0.00 \mathrm{c}$ & $0.39 \pm 0.02 \mathrm{ab}$ \\
\hline Total & 51.65 & 54.38 & 54.25 & 53.56 & 49.89 & 50.55 & 55.46 & 49.93 & 50.2 & 61.21 \\
\hline
\end{tabular}

${ }^{1)}$ All values are presented as the mean of triplicate determination. All values within a column with different superscript letters are significantly from each other at $p<0.05$ by Duncan's multiple range test 
Table 4 Changes of isoflavone contents in soybean leaf containing high isoflavone according to storage temperatures and periods

\begin{tabular}{|c|c|c|c|c|c|c|c|c|c|c|}
\hline \multirow{3}{*}{$\begin{array}{l}\text { Contents }{ }^{1)} \\
(\mu g / g \text { d.w. })\end{array}$} & \multicolumn{10}{|c|}{ TStorage periods / Temperature } \\
\hline & \multirow{2}{*}{0 day } & \multicolumn{3}{|c|}{60 day } & \multicolumn{3}{|c|}{120 day } & \multicolumn{3}{|c|}{180 day } \\
\hline & & 5 & 25 & 55 & 5 & 25 & 55 & 5 & 25 & 55 \\
\hline \multicolumn{11}{|l|}{$\overline{\beta \text {-Glycosides }}$} \\
\hline Daidzin (1) & $851.14 \pm 17.02 b$ & $923.26 \pm 36.93 \mathrm{ab}$ & $893.41 \pm 26.80 \mathrm{~b}$ & $1290.19 \pm 51.61 \mathrm{a}$ & $947.3 \pm 18.95 \mathrm{ab}$ & $869.51 \pm 17.39 b$ & $1299.46 \pm 25.99 \mathrm{a}$ & $955.24 \pm 9.55 \mathrm{ab}$ & $928.69 \pm 27.86 \mathrm{ab}$ & $1364.33 \pm 27.29 \mathrm{a}$ \\
\hline Genistin (2) & $496.64 \pm 14.90 \mathrm{c}$ & $563.08 \pm 11.26 \mathrm{bc}$ & $559.98 \pm 5.60 \mathrm{bc}$ & $810.63 \pm 16.21 \mathrm{a}$ & $585.28 \pm 17.56 b$ & $547.90 \pm 16.44 \mathrm{~b}$ & $796.03 \pm 31.84 \mathrm{ab}$ & $584.41 \pm 11.69 b$ & $579.92 \pm 11.60 \mathrm{~b}$ & $830.80 \pm 16.62 \mathrm{a}$ \\
\hline Total & 1347.78 & 1486.34 & 1453.39 & 2100.82 & 1532.58 & 1417.41 & 2095.49 & 1539.65 & 1508.61 & 2195.13 \\
\hline \multicolumn{11}{|c|}{ Malonyl- $\beta$-glycosides } \\
\hline Daidzin (3) & $1235.89 \pm 12.36 \mathrm{ab}$ & $1231.94 \pm 61.60 \mathrm{ab}$ & $1187.5 \pm 23.75 b$ & $810.63 \pm 8.11 b c$ & $1198.9 \pm 35.97 \mathrm{ab}$ & $1243.64 \pm 12.44 \mathrm{ab}$ & $741.43 \pm 14.83 c$ & $1307.47 \pm 26.15 \mathrm{a}$ & $1151.84 \pm 11.52 \mathrm{~b}$ & $718.87 \pm 21.57 \mathrm{c}$ \\
\hline Genistin (4) & $973.33 \pm 29.20 \mathrm{ab}$ & $1025.0 \pm 20.50 \mathrm{a}$ & $1010.45 \pm 30.31 \mathrm{a}$ & $673.47 \pm 13.47 \mathrm{ab}$ & $1020.48 \pm 20.41 \mathrm{a}$ & $956.93 \pm 19.14 \mathrm{ab}$ & $583.45 \pm 5.83 b$ & $1004.0 \pm 10.04 \mathrm{a}$ & $943.35 \pm 18.87 \mathrm{ab}$ & $570.61 \pm 11.41 b$ \\
\hline Total & 2209.22 & 2256.94 & 2197.95 & 1484.1 & 2219.38 & 2200.57 & 1324.88 & 2311.47 & 2095.19 & 1289.48 \\
\hline \multicolumn{11}{|l|}{$\overline{\text { Aglycones }}$} \\
\hline Daidzein (5) & $265.69 \pm 2.66 \mathrm{~b}$ & $313.28 \pm 9.40 \mathrm{ab}$ & $274.68 \pm 10.99 b$ & $347.98 \pm 10.44 \mathrm{a}$ & $331.83 \pm 9.95 \mathrm{a}$ & $241.52 \pm 2.42 \mathrm{~b}$ & $292.03 \pm 8.76 \mathrm{ab}$ & $312.22 \pm 9.37 \mathrm{ab}$ & $280.0 \pm 5.60 \mathrm{ab}$ & $356.48 \pm 10.69 a$ \\
\hline Genistein (6) & $77.1 \pm 3.08 \mathrm{bc}$ & $101.92 \pm 1.02 b$ & $83.0 \pm 0.83 \mathrm{bc}$ & $118.91 \pm 2.38 \mathrm{ab}$ & $111.84 \pm 4.47 \mathrm{ab}$ & $65.51 \pm 1.97 \mathrm{c}$ & $90.22 \pm 3.61 b c$ & $102.77 \pm 2.06 \mathrm{~b}$ & $83.47 \pm 2.50 \mathrm{bc}$ & $124.13 \pm 2.48 \mathrm{a}$ \\
\hline Total & 342.79 & 415.2 & 357.68 & 466.89 & 443.67 & 307.03 & 382.25 & 414.99 & 363.47 & 480.61 \\
\hline Total isoflavones & 3899.79 & 4158.48 & 4009.02 & 4051.81 & 4195.63 & 3925.01 & 3802.62 & 4266.11 & 3967.27 & 3965.22 \\
\hline \multicolumn{11}{|c|}{$\begin{array}{l}{ }_{1}^{1)} \text { All values are presented as the mean of triplicate determination. All values within a column with different superscript letters are significantly from each other at } p<0.05 \text { by Duncan's multiple } \\
\text { range test }\end{array}$} \\
\hline
\end{tabular}


및 $11.1 \mathrm{mg} / 100 \mathrm{~g}$ 로 약간 증가하여 180 일까지 비슷한 수준을 유 지하였으며, palmitic acid 및 stearic acid는 120 일까지는 0 일과 비교하여 낮은 함량을 나타내었으나 180 일에 palmitic acid는 각 각 $319.1\left(5^{\circ} \mathrm{C}\right), 349.1\left(25^{\circ} \mathrm{C}\right)$ 및 $314.1 \mathrm{mg} / 100 \mathrm{~g}\left(55^{\circ} \mathrm{C}\right)$ 으로 0 일에 비교하여 비슷하거나 높은 함량을 나타내었다. 그 밖의 포화 지방산은 초기에 비해 감소하였으며 대체로 60 일 함량 수 준으로 180 일까지 비슷한 수준을 유지하였다. 한편 불포화 지 방산은 $\alpha$-linolenic를 제외하고 0 일과 비교하여 60 일에 함량이 낮았으며 이후 저장이 진행됨에 따라 비슷한 수준을 유지하였 다. $\alpha$-Linolenic는 60 일까지 모든 저장온도에서 0 일에 비해 높 은 수준을 보였으나 이후 180 일까지 점차 감소하여 각각 465.9 $\left(5{ }^{\circ} \mathrm{C}\right), 507.2\left(25^{\circ} \mathrm{C}\right)$ 및 $384.2 \mathrm{mg} / 100 \mathrm{~g}\left(55^{\circ} \mathrm{C}\right)$ 로 저장 초기 와 비슷하거나 낮은 함량을 보였다. 저장 온도 및 기간에 따른 변화는 저장 초기에 비해 유의적인 차이를 보이지 않았지만, 55 ${ }^{\circ} \mathrm{C}$ 에서 180 일까지 고온 장시간 보관된 시료는 대체로 포화 지 방산은 증가하고 불포화 지방산은 감소하는 현상을 보였다.

콩잎 저장 조건(온도와 기간)에 따라 지방산 함량은 변화하 였지만 linolenic acid, palmitic acid, stearic acid 및 linoleic acid는 모든 저장 조건에서 월등히 높은 수준을 유지하였으며, 이러한 결과는 일반적으로 잎 채소의 지방산은 linolenic acid, linoleic acid 및 palmitic acid 함량이 월등히 많다고 보고한 Hitchcock와 Nicholas[24]의 연구결과와 유사한 경향을 나타내 었다. Sul 등[15]은 저장 온도에 따른 콩의 지방산 함량 변화는 $5{ }^{\circ} \mathrm{C}$ 에서 보관된 시료의 지방산 조성은 저장 초기와 비슷한 수 준이었고 25 와 $35^{\circ} \mathrm{C}$ 저장된 시료는 총 불포화 지방산 감소와 총 포화 지방산 증가한다고 보고하였고, 본 연구에서 콩잎 함 량의 변화를 보았을 때 $25^{\circ} \mathrm{C}$ 저장 시료에서 포화 및 불포화 지방산 함량이 저장 초기와 비슷하였으며 5 및 $55^{\circ} \mathrm{C}$ 저장 시 료의 포화 지방산은 비슷한 수준이었고 불포화 지방산은 감소 하는 경향을 보여 콩의 저장 시료와는 약간의 차이를 보였다. 이러한 경향은 비교적 불안정한 구조를 가지고 있는 불포화 지 방산이 공기 중에 산소, 빛, 열 등에 의해 산화되기 쉬어 55 ${ }^{\circ} \mathrm{C}$ 에서 보관된 콩잎에서 불포화 지방산 감소폭이 컸던 것으로 판단된다[25].

\section{저장 온도 및 기간에 따른 유리아미노산 조성 변화}

콩잎의 저장 온도 및 기간별 유리아미노산 함량의 변화를 살펴 본 결과 Table 2 과 같았다. 콩잎 0 일의 주요 아미노산은 aspartic acid- $\mathrm{NH}_{2}$ 와 urea으로 각각 326.86 및 $129.23 \mathrm{mg} / 100$ $\mathrm{g}$ 검출되었고 다음으로는 비필수아미노산 중 $\gamma$-aminobutyric acid와 proline이 비교적 높은 함량을 나타내었고, 그 밖에 필수 아미노산 중 valine과 phenylalanine이 각각 49.71 와 $42.94 \mathrm{mg}$ $100 \mathrm{~g}$ 로 비교적 높은 함량이 검출되었다. 저장 온도 5,25 및 $55{ }^{\circ} \mathrm{C}$ 에서 저장기간이 길어짐에 따라 아미노산의 함량은 유의 적인 변화를 보이지 않았다. 주요 아미노산인 aspartic acid- $\mathrm{NH}_{2}$ 의 아미노산 함량을 보면 5 와 $25^{\circ} \mathrm{C}$ 에서 60 일 동안 저장된 시 료에서 각각 425.95 와 $338.88 \mathrm{mg} / 100 \mathrm{~g}$ 으로 저장 0 일에 비해 증가하였고, $55^{\circ} \mathrm{C}$ 에서는 $227.85 \mathrm{mg} / 100 \mathrm{~g}$ 으로 감소하였다. 이후 180 일까지 감소 또는 증가하여 최종 180 일에 $409.97\left(5^{\circ} \mathrm{C}\right)$, $399.78\left(25^{\circ} \mathrm{C}\right)$ 및 $380.33 \mathrm{mg} / 100 \mathrm{~g}\left(55^{\circ} \mathrm{C}\right)$ 으로 3 가지 시료 모 두 0 일에 비해 높은 함량이 검출되었고, $5>25>55{ }^{\circ} \mathrm{C}$ 순으로 낮 은 온도에서 보관된 시료가 가장 높은 함량을 나타내었다. 필
수아미노산 중 대표적으로 valine의 분석결과 역시 60 일에 5 , 25 및 $55^{\circ} \mathrm{C}$ 각각 $61.89,52.41$ 및 $36.16 \mathrm{mg} / 100 \mathrm{~g}$ 이었으며 이 후 최종 180 일에는 $65.08,66.66$ 및 $65.28 \mathrm{mg} / 100 \mathrm{~g}$ 으로 0 일에 비해 높은 함량을 나타내었다. 필수아미노산 중 valine을 제외 한 나머지 아미노산은 180 일의 저장 온도별 시료에서 5>25> $55^{\circ} \mathrm{C}$ 순으로 0 일보다 높은 함량이 검출되었고 총 아미노산 함 량 역시 0 일에 $1313.81 \mathrm{mg} / 100 \mathrm{~g}$ 에서 180 일에 각각 1776.15 $\left(5{ }^{\circ} \mathrm{C}\right), 1693.93\left(25^{\circ} \mathrm{C}\right)$ 및 $1551.18 \mathrm{mg} / 100 \mathrm{~g}\left(55^{\circ} \mathrm{C}\right)$ 으로 높은 함량으로 검출되었다. 그 밖에 ammonia는 저장기간이 길어짐에 따라 증가하는 경향을 나타내어 0 일 $12.89 \mathrm{mg} / 100 \mathrm{~g}$ 에서 180 일 에 각각 $14.66\left(5^{\circ} \mathrm{C}\right), 14.52\left(25^{\circ} \mathrm{C}\right)$ 및 $17.70 \mathrm{mg} / 100 \mathrm{~g}\left(55^{\circ} \mathrm{C}\right)$ 으로 높은 함량이 검출되었다.

Sul 등[15]의 연구에 따르면 콩에 산성 아미노산인 glutamic acid 함량이 가장 높으며 저장 온도에 따른 콩의 아미노산 조 성 변화는 없는 것으로 보고되어 본 연구의 콩잎과는 상이한 결과를 나타내었고, 한편 함황아미노산인 cystein과 methionine 은 낮은 함량을 나타낸다고 보고하여 본 연구와 유사한 경향을 보였다.

\section{저장 온도 및 기간에 따른 무기질 조성 변화}

콩잎의 저장 온도 및 기간별 무기질 함량을 분석한 결과 Table 3 과 같았다. 분석결과 0 일 콩잎시료에서 $\mathrm{K}$ 가 $23.16 \mathrm{mg} / 100 \mathrm{~g}$, $\mathrm{Ca}$ 가 $19.00 \mathrm{mg} / 100 \mathrm{~g}$ 으로 주요 무기질로 검출되었으며 다음으 로 $\mathrm{P}, \mathrm{S}$ 및 $\mathrm{Mg}$ 가 각각 $2.87,2.96$ 및 $2.89 \mathrm{mg} / 100 \mathrm{~g}$ 으로 높은 함량을 보였고 나머지 무기질의 경우 $0.39 \mathrm{mg} / 100 \mathrm{~g}$ 이하로 검 출되었다. 각각 무기질 함량이 저장기간이 길어짐에 따라 큰 폭 의 변화를 보이진 않았지만 총 무기질 함량이 0 일 $51.65 \mathrm{mg}$ $100 \mathrm{~g}$ 에서 최종 180 일에 5,25 및 $55^{\circ} \mathrm{C}$ 저장온도에서 각각 $49.93,50.20$ 및 $61.21 \mathrm{mg} / 100 \mathrm{~g}$ 으로 5 와 $25^{\circ} \mathrm{C}$ 는 미량 감소하 였고 $55^{\circ} \mathrm{C}$ 에서는 저장 초기에 비해 높은 함량을 나타내었다.

$\mathrm{Kim}$ 등[25]의 연구에 따르면 모시잎의 무기질 함량은 $\mathrm{Ca}$ 와 $\mathrm{K}$ 의 함량이 높으며, Choi와 $\mathrm{Kim}[26]$ 은 참나물의 무기질 분석 결과 $\mathrm{K}$ 함량이 가장 높았으며 다음으로 $\mathrm{Ca}$ 와 $\mathrm{Mg}$ 순으로 함유 한 것으로 보고하였다. Ahn 등[27]은 방아잎 무기질 분석결과 $\mathrm{K}, \mathrm{Mn}, \mathrm{Mg}, \mathrm{Ca}$ 순으로 높은 함량을 나타낸다고 보고하였고, $\operatorname{Kim}[28]$ 은 사자발쑥의 무기질 함량은 $\mathrm{K}$ 와 $\mathrm{Ca}$ 의 함량이 높다고 보고하여 이상의 연구결과들에서 산채류 및 엽채류의 무기질 함 량은 대체로 $\mathrm{K}$ 이 가장 높은 함량을 나타내는 것으로 보고하였 으며 본 연구결과 콩잎 또한 이와 유사한 경향을 보였고 저장 온도 및 기간 전반에 걸쳐 그 함량을 큰 변화 없이 비슷한 수 준을 유지하였으며 한편 $55^{\circ} \mathrm{C}$ 에서 180 일간 보관된 시료에서는 무기질 함량이 미량 증가한 것으로 확인되었다. 일반적으로 비 타민은 공기, 빛, 열 등에 의해 쉽게 파괴되지만 무기질은 열, 빛 등에 의해 쉽게 파괴되지 않는 안정적인 영양소로 알려져 있어[29] 본 연구에서 또한 저장 온도에 따른 무기질의 변화가 미미했던 것으로 판단된다.

\section{저장 온도 및 기간에 따른 이소플라본 조성 변화}

6 종의 이소플라본 유도체 함량 변화를 살펴본 결과 Fig. 2와 Table 4와 같았다. Fig. 2에 나타난 바와 같이 배당체(peak 1; daidzin, peak 2; genistin, peak 3; malonyl daidzin, peak 4; malonyl genistin)와 비배당체(peak 5; daidzein, peak 6; 
genistein) 유도체 6종이 검출되었다. 0 일 콩잎은 주요 이소플라 본으로 malonyldaidzin, malonylgenistin 및 daidzin이 각각 $1235.89,973.33$, 및 $851.14 \mu \mathrm{g} / \mathrm{g}$ 으로 검출되었다. 비배당체 daidzein과 genistein은 각각 265.69 및 $77.10 \mu \mathrm{g} / \mathrm{g}$ 으로 검출되었 다. 저장 기간이 길어짐에 따라 daidzin과 genistin는 증가하는 경향을 보여 $55^{\circ} \mathrm{C}$ 에서 180 일 동안 보관된 시료에서 각각 1364.33 와 $830.80 \mu \mathrm{g} / \mathrm{g}$ 으로 가장 많은 함량으로 검출되었다. 반 면 malonyldaidzin과 malonylgenistin은 저장 기간이 길어짐에 따라 감소하는 경향을 나타내어 $55^{\circ} \mathrm{C}$ 에서 180 일 동안 보관된 시료에서 각각 718.87 및 $570.61 \mu \mathrm{g} / \mathrm{g}$ 으로 가장 낮은 함량을 보 였다. 비배당체의 경우 $25^{\circ} \mathrm{C}$ 에서 보관된 시료는 보관기간 중 비슷한 수준을 유지하였으며 5 와 $55^{\circ} \mathrm{C}$ 보관 시료는 약간 증가 하여 $55^{\circ} \mathrm{C}$ 에서 180 일 동안 보관된 시료에서 daidzein 및 genistein 각각 356.48 및 $124.13 \mu \mathrm{g} / \mathrm{g}$ 으로 검출되었다. 총 이소 플라본 함량은 0 일 $3899.79 \mu \mathrm{g} / \mathrm{g}$ 에서 저장 180 일에 5,25 및 $55^{\circ} \mathrm{C}$ 저장 시료 각각 $4266.11,3967.27$ 및 $3965.22 \mu \mathrm{g} / \mathrm{g}$ 으로 증가한 것을 확인하였다.

Yoon 등[11]은 콩잎 열수 추출물의 이소플라본 함량을 측정 한 결과 배당체인 daidzin과 genistin은 각각 0.45-5.84와 2.94$53.72 \mathrm{mg} / \mathrm{L}$ 이며, 비배당체인 daidzein과 genistein은 $0.26-0.61$ 와 $0.54-0.89 \mathrm{mg} / \mathrm{L}$ 로 미량 검출되었으며, Ryu 등[8] 연구에 따르면 푸른 콩잎은 이소플라본의 대부분이 배당체 형태로 존재하며, 노란 콩잎에는 배당체인 daidzein $(16.295 \mathrm{mg} \%)$ 및 genistein $(8.761 \mathrm{mg} \%)$ 이 검출된다고 보고하였고, 본 연구의 콩잎은 배당 체 및 비배당체 이소플라본 모두 높은 함량으로 검출되었다. Hwang 등[16]은 콩 품종별 이소플라본 함량을 분석한 결과 daidzin과 genistin은 각각 $167.62-373.58$ 와 $37.78-115.60 \mu \mathrm{g} / \mathrm{g}$, malonyl daidzin과 malonyl genistin은 각각 349.72-1341.24과 466.76-1518.67 $\mu \mathrm{g} / \mathrm{g}$ 이며 비배당체인 daidzein과 genistein은 $37.78-115.60$ 과 $42.48-110.59 \mu \mathrm{g} / \mathrm{g}$ 으로 본 연구의 콩잎의 이소플 라본 함량이 앞선 연구의 품종별 콩 시료에 비해 대부분 높게 검출되었다. Lee 등[30]는 8가지 품종 콩잎의 수확기별 이소플 라본 함량을 분석한 결과 수확기 중 5 월 중순에 수확한 콩잎에 서 대체로 높게 검출되었고, daidzein 및 genistein 함량이 각각 46.14-114.06과 62.85-111.08 $\mu \mathrm{g} / \mathrm{g}$ 수준으로 genistein은 본 연구 의 콩잎과 비슷한 수준이었으나 daidzein은 본 연구에서 2 배 이 상 높은 함량을 나타내었다. Lee와 $\mathrm{Cho[31]는} \mathrm{품종별} \mathrm{콩의} \mathrm{저}$ 장기간에 따른 비배당체 이소플라본의 함량을 분석한 결과 5 가 지 품종 모두 수확 후 1,2 년 기간이 지남에 따라 daidzein, glycitein 및 genistein 함량이 유의적으로 감소하는 경향을 나타 내어 본 연구는 이와 상이한 결과를 나타내었다.

\section{저장 온도 및 기간에 따른 총 phenolics 및 총 flavonoids 함 량 변화}

콩잎 저장 온도 및 기간별 총 phenolics 및 총 flavonoids 함량 을 측정한 결과 Fig. 1과 같았다. 저장 0 일째 총 phenolics 함 량은 $9.31 \mathrm{mg} / \mathrm{g}$ 이며, 저장기간이 길어짐에 따라 $5{ }^{\circ} \mathrm{C}$ 저장 시료 는 각 저장 기간별 시료가 0 일과 비슷하여 함량의 변화를 거의 보이지 않았다. 25 와 $55^{\circ} \mathrm{C}$ 저장 시료는 저장기간이 길어짐에 따라 약간 증가하는 경향을 나타내어 180 일에 각각 9.56 와 9.97 $\mathrm{GAE} \mathrm{mg} / \mathrm{g}$ 으로 $55^{\circ} \mathrm{C}$ 에서 180 일 저장 시료가 가장 높은 함량 으로 검출되었다. 하지만 모든 저장 조건별 시료의 총 phenolics


Fig. 1 Change of the total phenolic and flavonoid contents in soybean leaf containing high isoflavone according to storage temperatures and periods. (A) Total phenolic contents; and (B) Total flavonoid contents. All values are present as the mean $\pm \mathrm{SD}$ of pentaplicate determination. All values within a column with different superscript letters are significantly from each other at $p<0.05$ by Duncan's multiple range test

함량은 큰 차이를 보이진 않았다. 총 flavonoids 함량은 0 일 $8.61 \mathrm{mg} / \mathrm{g}$ 에서 저장기간이 길어짐에 따라 5,25 및 $55^{\circ} \mathrm{C}$ 저장 시료 모두 증가하는 경향을 보여 180 일에 각각 $8.94,9.08$ 및 $9.30 \mathrm{mg} / \mathrm{g}$ 으로 $5<25<55^{\circ} \mathrm{C}$ 순으로 높은 함량을 보였다.

Ziegler 등[32]은 수분 함량이 다른 콩을 저장온도별로 분석 한 결과 phenoilcs는 저장 초기에 비해 대체로 증가하였으며 그 증가 경향은 온도에 비례하지는 않았고, flavonoids는 수분 15 와 $18 \%$ 함유 콩은 저장 초기에 비해 저장 12 달 후 모든 온도 에서 증가하였으나, 수분 $12 \%$ 함유 콩은 11 와 $18^{\circ} \mathrm{C}$ 의 저장 시 료는 감소하였고 25 와 $32{ }^{\circ} \mathrm{C}$ 저장 시료는 증가하여 저장 온도 증가에 따른 유의적인 변화는 보이지 않아 본 연구의 콩잎과는 유사점을 찾기 어려웠다.

\section{저장 온도 및 기간에 따른 라디칼 소거활성 변화}

콩잎 저장 온도 및 기간별 라디칼 소거활성을 살펴본 결과 Fig. 3 과 같았다. $\mathrm{DPPH}$ 라디칼 소거활성은 저장 초기( 0 일) $30.91 \%$ 에서 $5{ }^{\circ} \mathrm{C}$ 보관 시료는 저장 기간 동안 비슷한 수준을 유지하 여 180 일은 $30.62 \%$ 였으며, $25^{\circ} \mathrm{C}$ 보관 시료는 역시 저장 기간 동안 큰 변화는 없었으며 최종 180 일에 $32.22 \%$ 를 나타내었다. $55{ }^{\circ} \mathrm{C}$ 저장 시료는 저장기간 따라 약간 증가하는 경향을 나타 내어 180 일에 $37.10 \%$ 로 가장 높은 활성을 나타내었다. ABTS 라디칼 소거활성은 저장 0 일 $55.98 \%$ 에서 5 와 $25{ }^{\circ} \mathrm{C}$ 저장 시료 는 180 일에 모두 $56.59 \%$ 로 기간별로 차이가 뚜렷하지 않았다. 한편, $55^{\circ} \mathrm{C}$ 저장 시료는 저장 기간에 따라 증가하여 180 일에 $62.54 \%$ 로 가장 높은 활성을 나타내었다. Hydroxyl 라디칼 소거 
(A)



(C)

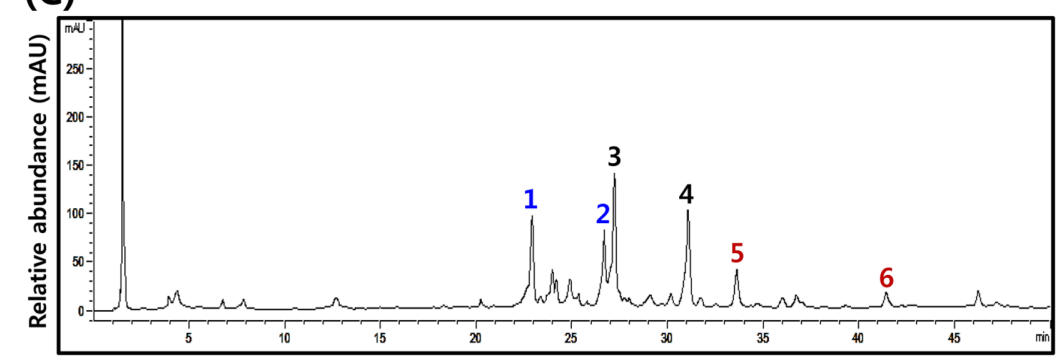

(E)

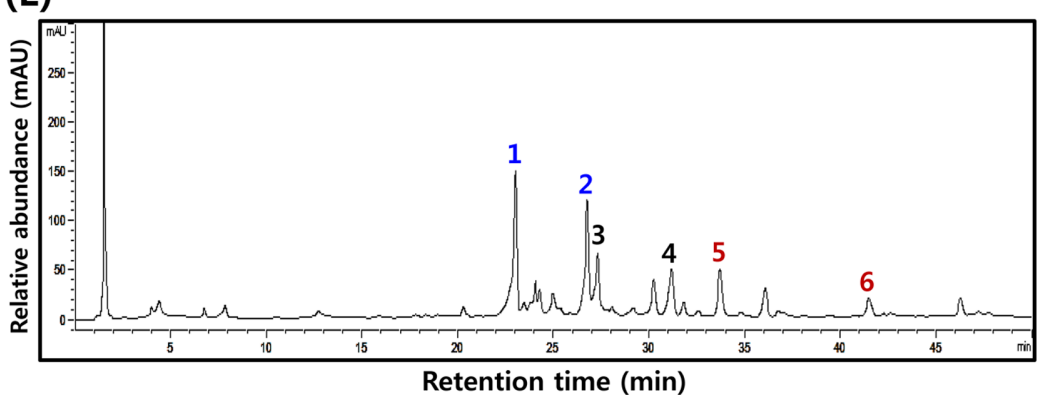

(B)

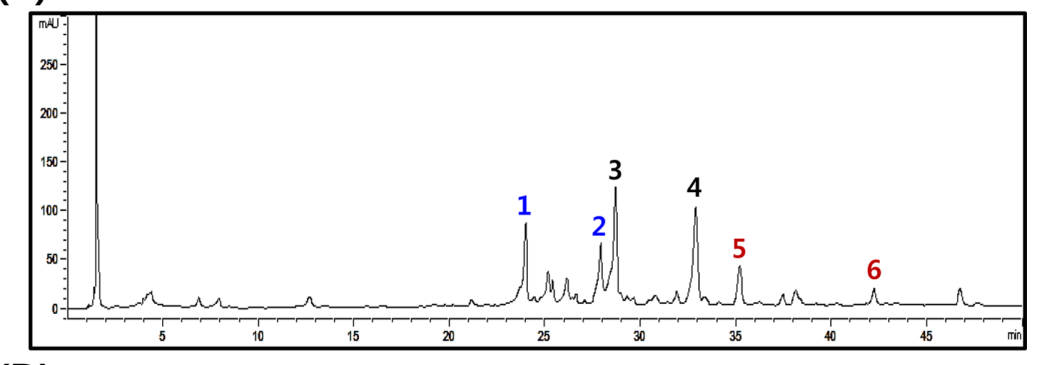

(D)



Retention time (min)

Fig. 2 Typical isoflavone HPLC chromatogram of the 50\% methanol extracts in soybean leaf containing high isoflavone according to storage temperatures and periods. (A) Standard; (B) Treatment concentration of ethephon: $0 \mathrm{mg} / \mathrm{L}$; (C) Treatment concentration of ethephon: $150 \mathrm{mg} / \mathrm{L}$; and (D) Treatment concentration of ethephon: $300 \mathrm{mg} / \mathrm{L}$. 1, Daidzin; 2, Genistin; 3, Manloyldaidzin; 4, Manloylgenistin; 5, Daidzein; and 6, Genistein 

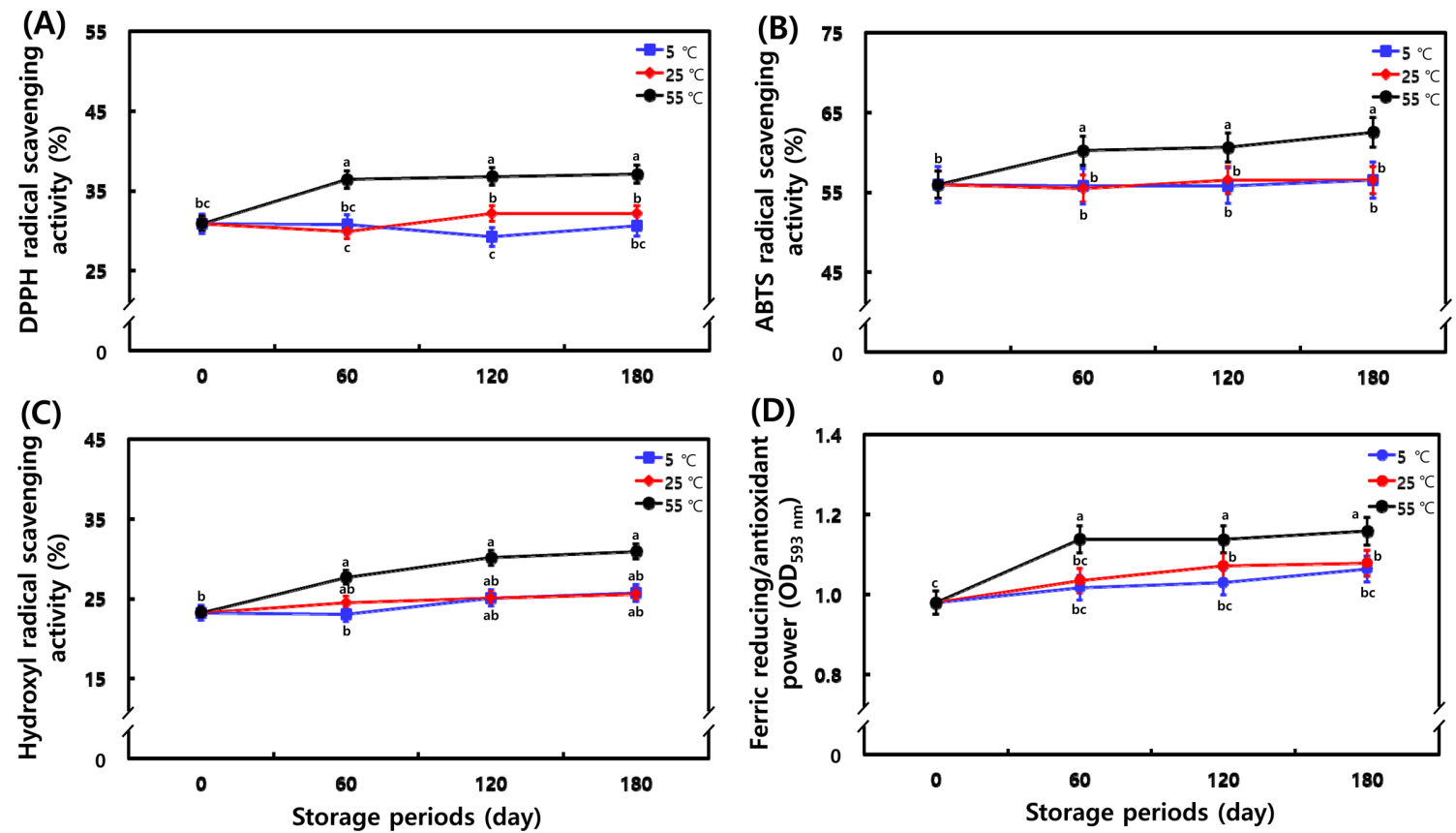

Fig. 3 Change of the antioxidant activity in soybean leaf containing high isoflavone according to storage temperatures and periods. (A) DPPH radical scavenging activity; (B) ABTS radical scavenging activity; and (C) Hydroxyl radical scavenging activity. All values are present as the mean \pm SD of pentaplicate determination. All values within a column with different superscript letters are significantly from each other at $\mathrm{p}<0.05$ by Duncan's multiple range test

활성은 모든 온도에서 저장기간이 지남에 따라 약간 증가하는 경향을 나타내어 0 일 $23.27 \%$ 에서 180 일은 각각 $25.76\left(5^{\circ} \mathrm{C}\right)$, $25.62\left(25^{\circ} \mathrm{C}\right)$ 및 $30.95 \%\left(55^{\circ} \mathrm{C}\right)$ 의 활성을 나타내었다.

$\mathrm{Lee}$ 와 $\mathrm{Cho[31]}$ 는 5 종의 콩을 상온에서 2년간 저장할 때 $\mathrm{DPPH}$ 와 $\mathrm{ABTS}$ 라디칼 활성을 분석한 결과 각 시료에서 $\mathrm{ABTS}$ 활성이 $\mathrm{DPPH}$ 활성보다 높게 나타나 본 연구의 경향과 일치하 였고, $\mathrm{DPPH}$ 와 $\mathrm{ABTS}$ 는 각각 저장 1 년후 약 $25 \%$ 감소, 약 2 년후 $40 \%$ 감소한다고 보고하여 기간이 지남에 따라 활성이 증 가하는 경향을 보인 본 연구와는 반대의 결과를 나타내었다. Ziegler 등[32]는 수분 함량이 다른 콩을 온도를 달리하여 저장 한 결과 저장 초기에 비해 저장 12 달 후 모든 온도에서 ABTS 활성이 증가하였고 저장 온도가 높아짐에 따라 활성이 유의적 으로 증가하는 경향을 보였고 같은 시료에서 $\mathrm{DPPH}$ 는 $\mathrm{ABTS}$ 보 다 낮은 활성을 보여 본 연구와 유사한 결과를 보였다. 본 연 구에서는 항산화 활성이 비배당체 이소플라본, 총 phenolics 및 총 flavonoids 함량과 관련이 있는 것으로 보이며, Kim 등[33] 또한 항산화 활성은 phenolics 및 이소플라본과 상관관계가 있 다고 보고하여 본 연구와 유사한 결과를 보고하였다. 한편 $\mathrm{ABTS}$ 라다칼 소거활성이 DPPH 및 hydroxyl 라디칼 소거활성 보다 높은 경향을 보였다. 이는 ABTS는 앞선 다양한 연구에서 보고된 바와 같이 peroxyl, hydroxyl, alkoxyl 및 inogranic radical와 반응하여 안정한 $\mathrm{ABTS}^{+}$형태의 양이온 라다칼을 형 성함으로[34] 항산화 물질에 대한 결합 능력의 차이가 발생한 다. 따라서 $\mathrm{ABTS}^{+}$는 친수성 물질과 소수성 물질의 항산화력 측정이 가능하므로 일반적으로 DPPH 및 hydroxyl과 비교해 높 은 라디칼 소거활성을 나타내는 것으로 판단된다[35].

본 연구에서는 고 이소플라본 함유 콩잎을 수확 후 건조하여
분말 형태로 5,25 및 $55^{\circ} \mathrm{C}$ 에서 180 일간 저장하면서 영양성분 과 생리활성물질, 항산화 활성 변화를 관찰한 결과 저장 온도 $55^{\circ} \mathrm{C}$ 에서 유리아미노산, 비대당체 이소플라본(daidzein과 genistein), 총 phenolics 및 총 flavonoids 함량이 약간 증가하 였으며, 이에 따라 라디칼 소거활성 역시 약간 증가하였다. 전 체적으로 저장 온도와 기간에 따른 성분 변화는 거의 없어 향 후 고 이소플라본 함유 콩잎의 수확 후 기능성 시료로서 사용 시까지 저장을 위한 기초자료를 제공할 수 있을 것으로 판단 된다.

\section{초 록}

본 연구는 고 이소플라본 함유 콩잎을 5,25 및 $55^{\circ} \mathrm{C}$ 에서 180 일간 저장하면서 지방산, 아미노산, 무기질, 이소플라본, 총 phenolics, 총 flavonoids 및 라디칼 소거활성 변화를 확인하였 다. 총 지방산 함량은 저장 기간에 따라 큰 차이를 보이지 않 았다. 총 아미노산 함량은 저장 0 일에 $1313.81 \mathrm{mg} / 100 \mathrm{~g}$ 에서 5 , 25 및 $55^{\circ} \mathrm{C}$ 에서 180 일째 각각 $1776.15,1693.93$ 및 1551.18 $\mathrm{mg} / 100 \mathrm{~g}$ 로 증가하였다. 총 무기질 함량은 저장 초기(51.65 $\mathrm{mg} / 100 \mathrm{~g}$ )에 비해 5,25 및 $55^{\circ} \mathrm{C}$ 에서 180 일째 각각 49.93, 50.20 및 $61.21 \mathrm{mg} / 100 \mathrm{~g}$ 로 검출되었다. 총 이소플라본 함량은 저장기간 중 비교적 큰 변화가 없었다. $55^{\circ} \mathrm{C}$ 에서 180 일 저장 의 경우, glycosides와 aglycones은 각각 2195.13 과 $480.61 \mu \mathrm{g} /$ $\mathrm{g}$ 로 증가하였으며, malonylglycosides는 $1289.48 \mu \mathrm{g} / \mathrm{g}$ 로 감소하 였다. 한편, 총 phenolics 및 총 flavonoids 함량은 0 일 저장 시 료에서 각각 9.31 과 $8.61 \mathrm{mg} / \mathrm{g}$ 에서 180 일째 각각 9.97 과 9.30 
$\mathrm{mg} / \mathrm{g}$ 으로 약간 증가하였고, 이에 상응하여 $\mathrm{DPPH}, \mathrm{ABTS}$ 및 hydroxyl 라디칼 소거활성은 저장 0일째 각각 30.91, 55.98 및 $23.27 \%$ 에서 180 일째 $37.10,62.54$ 및 $30.95 \%$ 로 증가하였다.

Keywords 아미노산·이소플라본·저장·지방산·콩잎-항산화

감사의 글 본 연구는 중소벤처기업부에서 지원하는 2018년도 산학연협력 기술개발사업(No. S2666938)의 지원과 2016년도 교육부와 한국연구재단의 기초연구사업(No. 2016R1D1A1B01009898)의 지원에 의해 이루어진 결과입 니다.

\section{References}

1. Hodgson JM, Croft KD, Puddey IB, Mori TA, Bellin LL (1996) Soybean isoflavonoids and their metabolic products inhibit in vitro lipoprotein oxidation in serum. Nutr Biochem 7: 664-669

2. Mitchell JH, Gardner PT, McPhail DB, Morrice PC, Collins AR, Duthie GG (1998) Antioxidant efficacy of phytoestrogens in chemical and biological model systems. Arch Biochem Biophy 360: 142-148

3. Lee BH, Kim KJ (2003) The physicochemical change of soybean-leaf water kimchis during fermentation. J East Asian Soc Dietary Life 13 601-607

4. Lee SH, Choi DJ, Kim JG (2003) Effect of salt concentration on soybean leaf kimchi fermentation. Korean J Food Preserv 10: 512-516

5. Lee SH, Choi DJ, Kim JG (2003) The effect of chitosan addition on soybean leaf kimchi fermentation. Korean J Food Preserv 10: 517-521

6. Ryu SH, Lee HS, Lee YS, Moon GS (2005) Contents of isoflavones and antioxidative related compounds in soybean leaf, soybean leaf jangachi, and soybean leaf kimchi. Korean J food Cookery Sci 21: 433-439

7. Kim SR, Je JH, Jeong JY, Kim HJ, Song YH, Park KH, Kang SS, Park SY (2017) Effect of soybean (Glycine max) leaf extract against the development of non-alcoholic fatty liver in high fat diet-fed mice. Yakhak Hoeji 61: 195-202

8. Kong SH, Lee DY, Bae JY, Song YH, Park KH, Jang KC, Kim JH (2018) Effect of postharvest treatment of ethylene of light on total flavonoid in soybean leaf. Korean J Pestic Sci 22: 152-157

9. Yoon JA, Kwun SY, Park EH, Kim MD (2019) Changes in isoflavone contents and physicochemical properties of soybean leaf extract by extraction conditions. Microbiol Biotechnol Lett 47: 64-68

10. Kwun SY, Yoon JA, Park EH, Kim MD (2019) Improving the aglycon isoflavone content in soybean leaf extracts by lactic acid fermentation. J Agri Life Sci 31: 160-170

11. Lin Z, Zhong S, Grierson D (2009) Recent advances in ethylene research. J Exp Bot 60: 3311-3336

12. Yuk HJ, Song YH, Curtis-Long MJ, Kim DW, Woo SG, Lee YB, Uddin Z, Kim CY, Park KH (2016) Ethylene induced a high accumulation of dietary isoflavones and expression of isoflavonoid biosynthetic genes in soybean (Glycine max) Leaves. J Agric Food Chem 64: 7315-7324

13. Saio K, Nikkynni I, Ando Y, Otsuru M, Terauchi Y, Kito M (1980) Soybean quality changes during model storage studies. Cereal Chem 57: 77-82

14. Saio K, Arisaka M (1978) Deterioration of soybean during storage under high moisture and temperature. Nippon Shokuhing Kogyo Gakkachi 25: $451-457$

15. Sul MS, Lee HJ, Yook HS (1998) Physicochemical properties of soybean as influenced by storage temperatures. J Korean Soc Food Sci Nutr 27: 827-832

16. Hwang CE, Kim SC, Lee JH, Lee DH, Cho KM (2019) Comparison of primary and secondary metabolite compositions and antioxidant effects of specific soybean cultivars. Korean J Food Preserv 26: 555-565
17. Hwang CE, Haque MA, Lee JH, Joo OS, Kim SC, Lee HY, Bong Sik Um BS, Park KS, Cho KM (2018) Comparison of $\gamma$-aminobutyric acid and isoflavone aglycone contents, to radical scavenging activities of high-protein soybean sprouting by lactic acid fermentation with Lactobacillus brevis. Korean J Food Preserv 25: 7-18

18. Kim ST, Jang JH, Kwon JH, Moon KD (2009) Changes in the chemical components of red and white ginseng after puffing. Korean J Food Preserv 16: 355-361

19. Lee JH, Hwang CE, Cho EJ, Song YH, Kim SC, Cho KM (2018) Improvement of nutritional components and in vitro antioxidative properties of soy-powder yogurts using Lactobacillus plantarum. J Food Drug Anal 26: 1054-1065

20. Singleton VL, Rossi JA (1965) Colorimetry of total phenolics with phosphomolybdic phosphotungstic acid reagents. Am J Enol Vitic 16: 144-158

21. Lee JH, Seo WT, Cho KM (2011) Determination of phytochemical contents and biological activities from the fruits of Elaeagnus multiflora. J Food Sci Nutr 16: 29-36

22. Hwang CE, An MJ, Lee HY, Lee BW, Kim HT, Ko JM, Baek IY, Seo WT, Cho KM (2014) Potential probiotic Lactobacillus plantarum P1201 to produce soy-yogurt with enhanced antioxidant activity. Korean J Food Sci Technol 46: 556-565

23. Lee JH, Hwang CE, Son KS, Cho KM (2019) Comparisons of nutritional constituents in soybeans during solid state fermentation times and screening for their glucosidase enzymes and antioxidant properties. Food Chem 272: 362-371

24. Hitchock C, Nicholas BW (1971) The lipid and fatty acid composition of specific tissues. In Plant Lipid Biochemistry. Academic Press, New York

25. Kim AR, Lee HJ, Jung HO, Lee JJ (2014) Physicochemical composition of ramie leaf according to drying methods. J Korean Soc Food Sci Nutr 43: $118-127$

26. Choi MH, Kim GH (2002) A study on quality characteristics of Pimpinella brachycarpa Kimchi during storage at different temperatures. J Korean Soc Food Sci Nutr 31: 45-49

27. Ahn B, Yang CB (1991) Chemical composition of Bangah (Agastache rugosa O. Kuntze) herb. Korean J Food Sci Technol 23: 375-378

28. Kim EM (2011) Antioxidant and anticancer effects of extracts and components from Artemisia princeps Pampanini and Cirsium setidens Nakai. J East Asian Soc Dietary Life 21: 871-876

29. Fennema OG (1996) Food Chemistry. 3rd ed. Marcel Deckker, New York. 547-551

30. Lee JH, Ha TJ, Baek IY, Ko JM, Cho KM, Im MH, Choung MG (2009) Characterization of isoflavones accumulation in developing leaves of soybean (Glycine max) cultivars. J Korean Soc Appl Biol Chem 52: 139-143

31. Lee JH, Cho KM (2012) Changes occurring in compositional components of black soybeans maintained at room temperature for different storage periods. Food Chem 131: 161-169

32. Ziegler V, Vanier NL, Ferreira CD, Paraginski RT, Fernandes Monks JL, Elias MC (2016) Changes in the bioactive compounds content of soybean as a function of grain moisture content and temperature during long-term storage. J Food Sci 81: 762-768

33. Kim JH, Hwang CE, Lee CK, Lee JH, Kim GM, Jeong SH, Shin JH, Kim JS, Cho KM (2014) Characteristics and antioxidant effect of garlic in the fermentation of Cheonggukjang by Bacillus amyloliquefaciens MJ1-4. J Microbiol Biotechnol 24: 959-968

34. Lee SO, Kim MJ, Kim DG, Choi HJ (2008) Antioxidative activities of temperature-stepwise water extracts from Inonotus obliquus. J Korean Soc Food Sci Nutr 34: 139-147

35. Re R, Pellegrini N, Proteggente N, Pannala A, Yang M, Rice-Evans C (1999) Antioxidant activity applying an improved ABTS radical cation decolorization assay. Free Radical Bio Med 26: 1231-1237 